Portland State University

PDXScholar

Summer 8-20-2019

\title{
The Influence of Neighborhood Landscape Characteristics on Native Bird Communities: Implications for Increasing Biodiversity in Our Yards
}

Michael E. Vermeulen

Portland State University

Follow this and additional works at: https://pdxscholar.library.pdx.edu/open_access_etds

Part of the Environmental Sciences Commons

Let us know how access to this document benefits you.

\section{Recommended Citation}

Vermeulen, Michael E., "The Influence of Neighborhood Landscape Characteristics on Native Bird Communities: Implications for Increasing Biodiversity in Our Yards" (2019). Dissertations and Theses. Paper 5130.

https://doi.org/10.15760/etd.7009

This Thesis is brought to you for free and open access. It has been accepted for inclusion in Dissertations and Theses by an authorized administrator of PDXScholar. Please contact us if we can make this document more accessible: pdxscholar@pdx.edu. 
The Influence of Neighborhood Landscape Characteristics on Native Bird Communities:

Implications for Increasing Biodiversity in Our Yards

by

Michael E. Vermeulen

A thesis submitted in partial fulfillment of the requirements for the degree of

Master of Science

in

Environmental Science and Management

Thesis Committee:

Marion Dresner, Chair

Michael Murphy

Catherine de Rivera

Portland State University

2019 
(C)2019 Michael E. Vermeulen 


\begin{abstract}
Avian communities, because of their potential high diversity, are ideal for studying the response to potential quantity of resources provided by local and regional habitat. Urban neighborhoods vary in types and magnitudes of anthropogenic stressors they experience, resulting in a continuum of anthropogenic disturbance, often referred to as a gradient of urbanization. The aim of this study was to investigate anthropogenic drivers of urban bird communities in three Portland, OR neighborhoods (Hillsdale, Lents, and Pearl). The three major questions of this study were: 1) What are the significant landscape traits that characterize the neighborhoods? 2) Is there evidence that the urban matrix may host similar avian community assemblages as neighborhood green space? And 3) Are landscape characteristics able to predict native bird communities, and if so, what scale is most explanatory?

Neighborhoods were sampled for three months (May - July, 2018) during the breeding season of local birds. Utilizing a community-based approach, parks $(n=17)$ and neighborhood residential areas $(n=34)$ were sampled using 50 -meter point counts. Community attributes (richness, abundance, and diversity) were compared to landcover (percent canopy, herbaceous and grass, and impervious surface cover), anthropogenic factors (population density and building density), and front-yard vegetative characteristics. Neighborhoods differed in degree of urbanization, with Hilldale being the least urbanized, Lents intermediate, and Pearl the most urbanized. My study found that Portland's urban and suburban avian communities are dominated by relatively few species (13 account for $\sim 98 \%$ of observations).
\end{abstract}


Differences between native avian community attributes were detected by neighborhood but avian communities did not respond strongly to gradient analysis or regression modeling with landcover characteristics. Within neighborhoods, habitat patches had differing levels of native bird diversity. Recreational parks, on average, tended to have lowest bird diversity when compared to residential sites and nature parks. Though few species were represented, avian guilds responded to urban gradients within neighborhoods. Foliage gleaners and insectivores were seen to decrease with increasing urbanization, whereas omnivorous birds increased. This shift in avian guild abundance indicates that species with more specialized traits did less well in more urban areas when compared to generalist species such as omnivores. 


\section{Acknowledgements}

I would first like to thank my thesis committee, Dr. Marion Dresner, Dr.

Catherine de Rivera, and Dr. Michael Murphy for all the support and guidance they gave me throughout this project. Thank you to the Bushby Award for helping fund this research. I am also grateful to all of my BirdCountPDX participants, you were instrumental in the success of this research. Thank you as well to Devin Van Leuven for all the assistance in the field, I know it could be awkward staring into peoples' front yards, but you were a great help!

The support from family and friends is what really made this work possible. Thank you, Emily, my partner in all I do, for always being my greatest advocate. Thank you to my parents, Mary and Pete for helping me get to this point in life, and thank you Sally and Herb for the unlimited coffee and paper edits! 


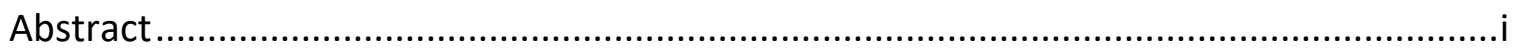

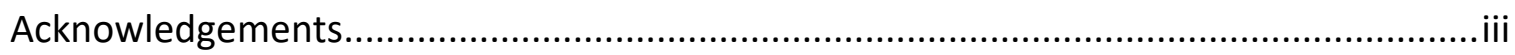

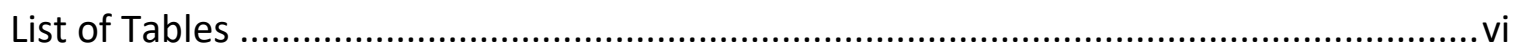

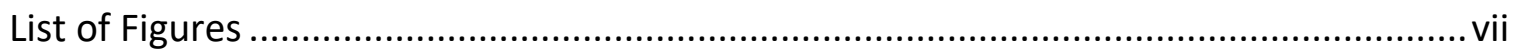

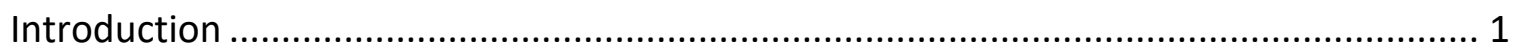

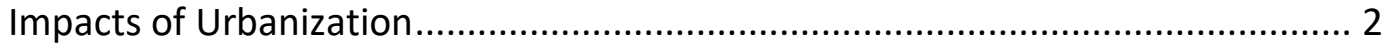

Avian Ecosystem Services ............................................................................. 4

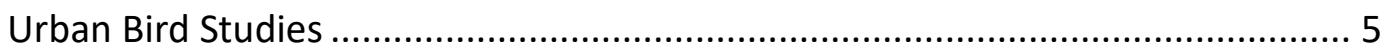

Island Biogeography................................................................................. 6

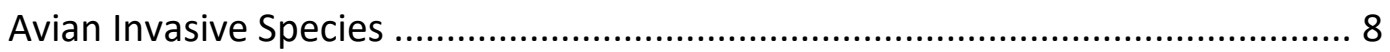

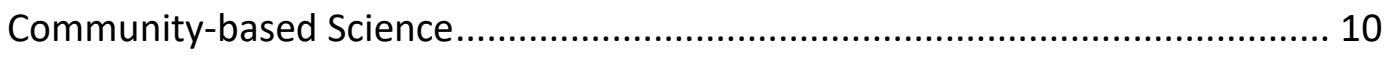

Aims of this Project ....................................................................................... 10

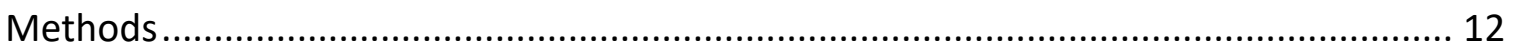

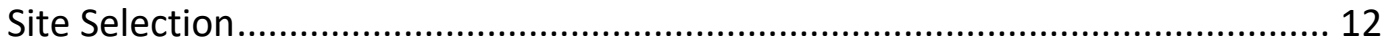

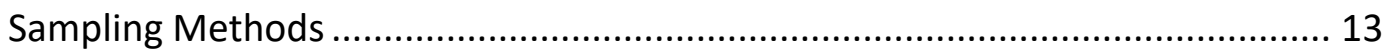

Community-based Science.......................................................................... 14

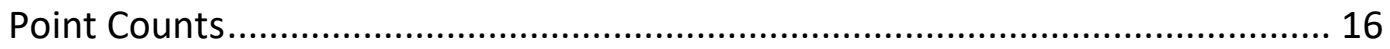

Front Yard Vegetation Surveys .................................................................. 17

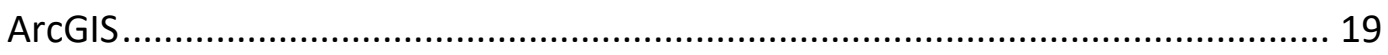

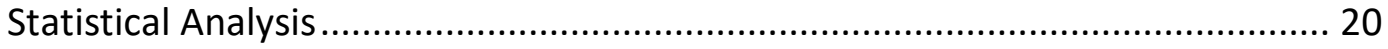

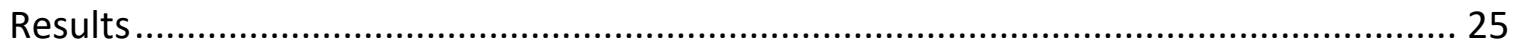

Neighborhood Landscape Traits ................................................................. 25 


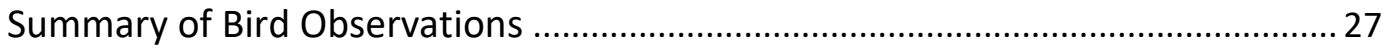

Native Species: Differences Within and Between Neighborhoods .................... 30

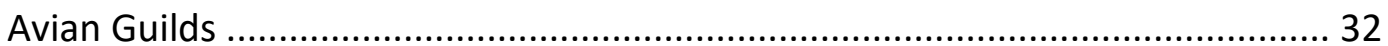

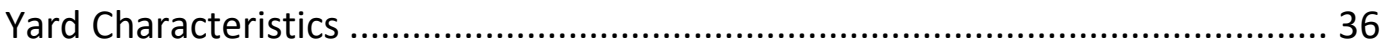

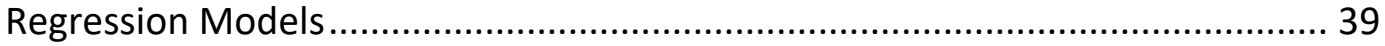

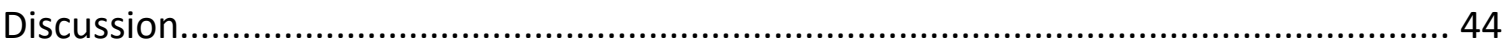

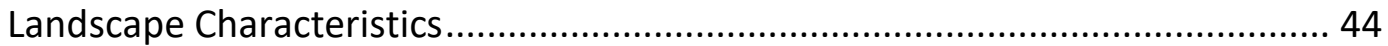

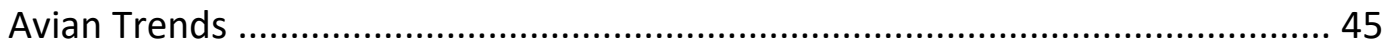

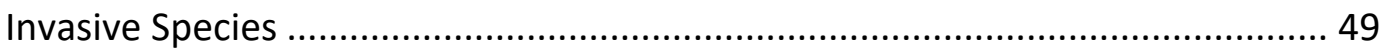

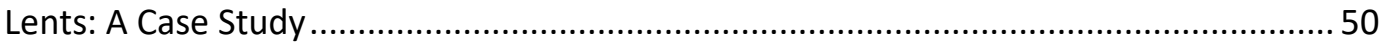

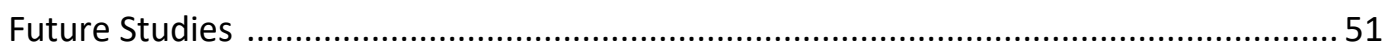

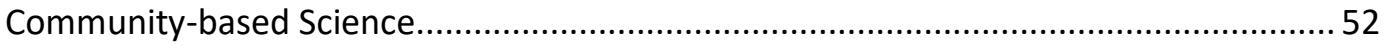

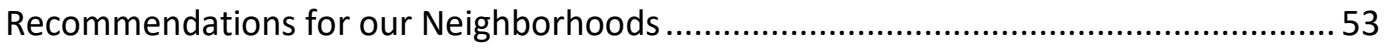

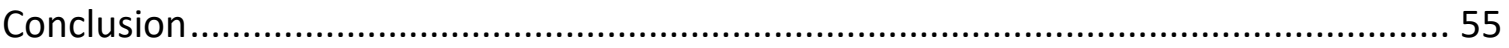

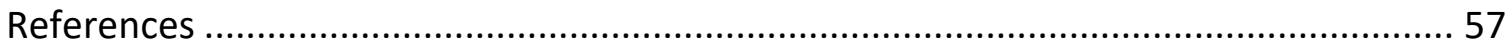

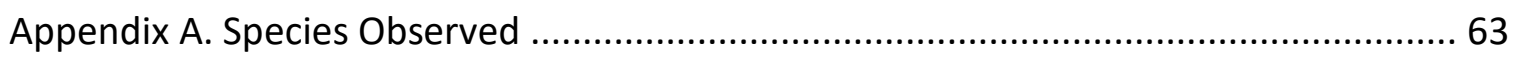

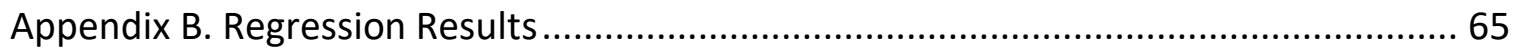




\section{List of Tables}

Table 1: Types and counts of stations within each neighborhood

Table 2: Scoring for breeding bird behavior

Table 3: Factor loadings of PC1 and PC2 from PCA of landscape traits 25

Table 4: Factor loadings of PC1 and PC2 from PCA of human disturbance variables

Table 5: Estimated regression coefficients for landscape variables

Table 6: Full model of local-landscape variables

Table 7: Models predicting avian community traits in residential areas with yards 43 


\section{List of Figures}

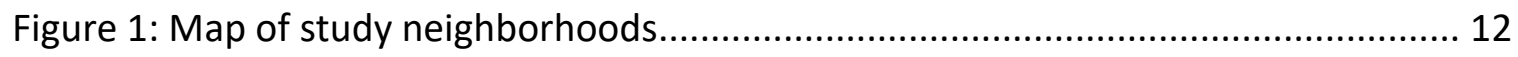

Figure 2: Representation of the five vegetation layers measured in front yards

Figure 3: PCA analysis plotting stations based on 8 landscape variables

Figure 4: Top 13 most abundant species observed

Figure 5: Species area relationships for yards, parks, and neighborhoods

Figure 6: Species accumulation curves depicting species richness by the total count of stations visited

Figure 7: Comparisons of untransformed average abundance, diversity, and species richness between neighborhoods

Figure 8: Variations between neighborhoods and along UI for avian foraging guilds, diets, and nesting guilds 34

Figure 9: Average proportion of all stations' vegetative cover by neighborhood 


\section{Introduction}

Over half of the world's population currently resides within urban areas. The number of people living areas are expected to by 72 percent, up to 6.3 billion people by 2050 (Zhang, 2016). This trend is experienced in many parts of the world, for instance, Portland's metropolitan area faces continued population and development growth. In Portland, Oregon, human population is expected to increase by 3.4 million people by 2060 (Hagerman, 2007) that will inevitably expand its footprint outward. This pattern of development, which pushes the geographic expansion of urban areas, results in strong gradients of urbanization and population density (Marzluff, Bowman, \& Donnelly, 2001). Urban-rural gradient studies consistently show changes in avian species richness and species composition along the gradient (McKinney, 2002). As worldwide biotic homogenization is seen, (Aronson et al., 2014) many urban areas are faced with high levels of local extinction along with the "extinction of experience" (McKinney, 2002; Miller, 2005). Those who are able to influence urban habitat (e.g. urban planners and private landowners) must find ways to preserve urban biodiversity as cities expand.

Birds are one of the most studied urban taxa (Marzluff, 2001) and arguably the most observed form of wildlife in metropolitan areas (Hedblom, Knez, \& Gunnarsson, 2017). As birds occupy a wide array of trophic levels and have the ability to fly, they provide us with a reflection of regionally available resources. This study aims to understand the influence of urban landscape characteristics on avian populations in three Portland, Oregon neighborhoods: Hillsdale, Lents, and Pearl. These three neighborhoods reflect levels of urbanization ranging from habitat rich parks in the 
suburban neighborhood of Hillsdale, to the city center in Pearl. Understanding differences between bird communities between and within these neighborhoods can help us better realize the influence we have on local biodiversity. Further, results of urban studies of diversity can help inform local municipality level landscape management, and private landowners about ongoing conservation needs.

Impacts of Urbanization

Urbanization is the process by which humans transform natural landscape to an anthropogenic landscape dominated by residential areas, downtown and industrial centers, and transportation corridors (Luck \& Wu, 2002). The urban landscape is a mosaic of different land uses, habitat types, and sociodemographic patterns (Luck \& Wu, 2002). Urban ecology, as a landscape-scale study, looks to understand the interactions between spatial patterns and ecological processes (Luck \& Wu, 2002). Anthropogenic disturbance such as pollution, traffic, and development occur across an urbanizing landscape, over large time scales, and at different magnitudes (Alberti \& Marzluff, 2004). These socioeconomic processes effect ecosystem processes within the urban landscape, providing us with a unique opportunity to study ecological responses to anthropogenic disturbance (McDonnell \& Pickett, 1990).

My study lies within the ecology-of-cities paradigm, which views urban ecosystems as an interconnected system of anthropogenic activity, human social systems, and the environment (Goddard, Dougill, \& Benton, 2009). This paradigm realizes that areas undergoing urbanization are unique from each other and likely 
experience varying steady and unstable states (Alberti \& Marzluff, 2004). The multiple possible pathways a city may respond to urbanization necessitates a multitude of studies be conducted across the world, so we can better understand commonalities across time and space. These commonalities can help us better develop mitigation and restoration strategies. This paradigm necessitates a landscape scale approach to understanding urban ecology and its interface with anthropogenic influences. As a starting point for my work I have adapted Marzluff et al.'s (2001) definition of urbanization and define it as the ways which we gradually alter undeveloped lands to a landscape where humans intend to reside indefinitely. As the relative degree of urbanization increases in older urban areas, and new urbanization appears around the older core, the gradient of urbanization begins. Marzluff et al (2001) identified five locations along an urbanization gradient: urban, suburban, exurban, rural, and wildland (listed by decreasing levels of urbanization). As there is no "set-in-stone" pattern for urban gradients, it is common to define a location's placement on the urban gradient by its percent-built land, building density or residential human density (Marzluff, 2001).

Luck and Wu (2002) detected the presence of an urban gradient in their combined gradient analysis and landscape metrics study in the metropolitan area of Phoenix, Arizona, USA. Their results showed that as you neared the urban center of Phoenix, habitat patches became smaller and more variable in size and shape, and that the landscape was overall more fragmented. Their results show empirical evidence for the presence of urbanization gradients and have broad ecological implications. 
Using an urbanization gradient approach allowed me to view the three neighborhoods included in my study (Hillsdale, Lents, and Pearl) as existing along a continuum rather than as three unrelated areas. The fact that all three neighborhoods lie within Portland's city limits means that they are all experiencing similar, yet different magnitudes, of anthropogenic disturbance. Further, it recognizes that each neighborhood may range through multiple parts of the urban gradient. For instance, some neighborhoods may range from highly urban sites to exurban sites.

\section{Avian Ecosystem Services}

Birds are well-loved neighborhood residents. Birdwatching is a popular activity and people go to great lengths providing food in their yards, to draw in more birds. Many people even vary the type of food they provide, hoping to bring in a greater diversity of species (a very clear reflection of peoples' valuing of diversity). Birds are arguably one of the most, if not the most interacted with urban form of "wildlife" (Hedblom, Knez, \& Gunnarsson, 2017). Despite our efforts to draw in more birds, typically native, we are faced with the contradiction that urban areas can be harmful to native bird diversity and often facilitate ecologic invasions by species such as the European starling (Sturnus vulgaris) and House Sparrow (Passer domesticus) (Crooks, Suarez, \& Bolger, 2004; Donnelly \& Marzluff, 2006; Lepczyk et al., 2017).

Birds provide a number of ecosystem services that generally fall into two categories, behavior-driven and product-driven services (those which are byproducts of behavior) (Whelan, Wenny, \& Marquis, 2008). Prominent examples of behavior-driven 
services are pest control (insects and rodents) provided by insectivorous birds and birds of prey, pollination, seed dispersal, and consumption of waste by scavengers (i.e., vultures) and generalists such as corvids (Whelan et al., 2008). Product-driven services are the production of cavities, by birds such as woodpeckers (Ingold, 1994). These cavities are then later used by secondary cavity nesting species (Whelan et al., 2008). Though there are a myriad of services provided by birds in urban areas, they are often not distributed equally throughout the urban landscape.

\section{Urban Bird Studies}

Urban birds are widely studied, especially in the global north (Marzluff, 2016). Most studies have focused on the pattern by which bird abundance or diversity have responded to urbanization (Marzluff, 2016). Several dominant patterns of species richness and abundance have emerged. For instance, moderate levels of urbanization, seen in suburban or exurban areas are associated with peak diversity (Marzluff, 2016; McKinney, 2002). High levels of urbanization, where most land has been converted to city, have been associated with very low bird diversity. In areas of high urbanization, only a few anthropocentric species comprise the community (Aronson et al., 2014; Marzluff, 2001, 2016). Urban bird studies has revealed that there are multiple ways to study how birds respond at the community level to human disturbance., but most studies have examined these responses across a gradient of urbanization (FernándezJuricic \& Jokimäki, 2001; Marzluff, 2016). 
In addition to species richness responses to urbanization, urbanization also appears to be a filter that eliminates some species based on their biological and behavioral traits (Conole \& Kirkpatrick, 2011). Urban adaptive birds are often shown to be generalist foragers, granivores or aerial insectivores, using either cavities, canopy, or urban substrates for nesting (Chace \& Walsh, 2006; Conole \& Kirkpatrick, 2011; Vignoli, Scirè, \& Bologna, 2013). Urban avoiders respond negatively to urbanization and are often associated with insectivorous foragers and gleaners which nest on the ground, canopy, or shrub layer (Conole \& Kirkpatrick, 2011).

\section{Island Biogeography}

The theory of Island Biogeography (MacArthur and Wilson 1967) has been utilized to study the effects of isolation and/or fragmentation of habitats on bird assemblages (Nielsen, van den Bosch, Maruthaveeran, \& van den Bosch, 2014). Habitat fragmentation in cities is any process that disrupts habitat continuity (Wiens, 1995). Fragmented habitat is located within a developed matrix, which is generally thought to have a negative influence on species richness (Nielsen et al., 2014; Wiens, 1995). Urban parks have been shown to positively influence avian community attributes such as richness, abundance, and diversity (Fernández-Juricic \& Jokimäki, 2001; Wiens, 1995) and are therefore often referred to as habitat islands nestled within an inhospitable urban matrix.

Large, predominantly vegetated parks have been shown to be highly diverse and host a large proportion of a regions native bird species (Donnelly \& Marzluff, 2004; 
Nielsen et al., 2014). For instance, large urban reserves in Seattle, WA, supported richer but less even bird communities than small reserves. Further, they found that reserves greater than 42 ha hosted most native bird species associated with native forest habitat, even when surrounded by more than $40 \%$ urban land cover (Donnelly \& Marzluff, 2004). These relationships between park size and native species richness are consistent with island biogeography's view that smaller habitat islands are more isolated, have greater ratios of edge to interior, and are more susceptible to disturbance events (Wiens, 1995). Large reserves and parks within the city may host the most diverse and rich bird communities, but they are not viable options for many already developed areas. The extent to which small urban green spaces can host native bird communities is not as well known, and a better understanding of their potential as viable wildlife habitat to help local municipalities better manage public spaces is needed.

The matrix is the variable mosaic of land between habitat patches. The matrix within cityscapes has generally been shown to support lower levels of species richness and to be "poorer" quality habitat for native bird assemblages (Belaire, Whelan, \& Minor, 2014). Though highly urban areas have a matrix dominated by paved surfaces and elevated rates of human disturbance (Luck \& Wu, 2002; Marzluff \& Ewing, 2001), residential neighborhoods have the potential as a type of matrix to be managed for conservation (Belaire et al., 2014). Residential yards comprise a large proportion of land area within the United States. Over 92 million acres of land are privately developed, much of which is by homeowners (NRCS, 1998/2007). Within the UK, private gardens have been shown to make up at over one third of the city land area (Mathieu, Freeman, 
\& Aryal, 2007). If groupings of yards are able to create connected habitat they may be able to increase native bird richness within the matrix (Belaire et al., 2014).

Despite this potential conservation value, residential yards remain relatively unstudied. Existing studies show that individual yard practices may "scale up" to effect urban biodiversity (Belaire et al., 2014). Yards with a greater proportion of native plants have been correlated with greater breeding success of native insectivorous birds (Narango, Tallamy, \& Marra, 2017). There is evidence that native plants increase the abundance and diversity of invertebrates, which birds prey on (Narango et al., 2017; Smith, Gaston, Warren, \& Thompson, 2006; Smith, Warren, Thompson, \& Gaston, 2006). Yards also have been shown to have the potential to increase the footprint of small habitat patches (Chamberlain, Gough, Vaughan, Vickery, \& Appleton, 2007). Viewed as such, conservation focused yards have the ability to soften the matrix, increasing its permeability and local habitat connectivity (Soga, Yamaura, Koike, \& Gaston, 2014).

\section{Avian Invasive Species}

As invasive species, birds are generally less successful than other classes of animals. Only about $30 \%$ of introduced birds succeed versus the $66 \%$ and $83 \%$ success rates for fish and mammals respectively (Aronson et al., 2014; Jeschke \& Strayer, 2005). Invasive birds dominate certain ecological niches in metropolitan areas, such as Rock Pigeons (Columba livia) in urban downtowns. The degree to which urbanization disrupts native bird diversity can be described by the dissimilarity of built environments compared to local natural habitat and the persistence of change (Marzluff \& Ewing, 
2001). It holds that more urban areas have a greater proportion of urban land cover, are more dissimilar to their surrounding "natural" matrix, provide constant disturbance through human activities, and have a greater abundance of invasive species.

What makes invasive species successful in highly urbanized areas may also help them in areas that are less subject to human disturbance. It has been proposed that invasive cavity nesters, such as Starlings and House Sparrows, outcompete native species for available cavities and that their synanthropic relationship allow them to more successfully raise their young in urban settings (Ingold, 1994, 1996; Koenig, 2003; Linz et al., 2007). The well recorded decline of bluebirds (Sialia spp.) in North America is speculated to be in part because of the aggressive behavior of starlings and House Sparrows (Gowaty, Patricia, 1984). Additionally, it has been shown that Northern Flickers (Colaptes auratus), a common urban cavity nester, delay their nesting period in the presence of starlings (Ingold, 1996). Delayed nesting has a cost as it is associated with significantly reduced clutch size, and number of nestlings and fledglings (Ingold, 1996). Despite the appealing argument that aggressive invasive cavity nesting birds can lead to declines of native cavity nesting birds, Koeing (2003) used Christmas Bird Count and Breeding Bird Surveys to show that only one native species out of 27 that was possibly affected negatively by starlings. Though this contradicts the expected trends, the issue may lie in the historical timeframe investigated. If starlings had already been introduced into the study area before the historical records under examination, it is possible that populations of native cavity nesting birds had already declined. 


\section{Community-based Science}

Community-based science is the meaningful involvement of community members as researches within a scientific investigation (Conrad \& Hilchey, 2011). The term "community-based science" is synonymous with "citizen science", but I will use the former in this paper throughout. Community-based science recognizes the importance of all peoples' participation, not just those who are recognized citizens of the United States. Mobilizing large numbers of individuals to help collect data enables the formation of large-scale data-gathering networks, allows data to be continuously collected, and has the potential to create more robust datasets than an individual researcher could develop (Bonney et al., 2009).

Bird monitoring programs in particular are especially suited to community-based science. Birds are predominantly active during daylight hours, are easily observed, and are great indicators because they are linked to a variety of processes at different trophic levels (Sullivan et al., 2009). Additionally, birding is already a well-established pastime for many individuals, making it easier to find potential volunteers. A number of organizations, such as the Cornell Lab of Ornithology and the Audubon Society, have successfully utilized community-based science to develop large nationwide monitoring programs (Conrad \& Hilchey, 2011).

\section{Aims of this Project}

Though birds are widely studied taxa in many cities across the world, each city presents a new challenge and potentially new insights, and the only published study of 
urban bird from Portland is that of Henning and Edge (2003), and that study focused on bird communities occupying narrow riparian strips. As there are no known studies addressing patterns of urbanization within Portland, this study seeks to characterize landscape traits of three study neighborhoods (Hillsdale, Lents, and Pearl). Green spaces within cities are prominently referred to as habitat islands within a hostile matrix. This prompted me to study both parks and residential sites, in order to compare community assemblages. Characterizing landscape and observing avian communities during the same field season enables me to describe responses in Portland's native bird richness, abundance, and diversity based on predictive landscape variables, the abundance of invasive species at each station, and vegetative layers within suburban front yards. The aims of this project have led me to pose three major questions: first, how do landscape characteristics vary between and within neighborhoods? Second, is there evidence that the urban matrix may host similar avian community assemblages as neighborhood green spaces? And third, are landscape characteristics able to predict native bird communities, and if so, what scale is most explanatory? 


\section{Methods}

\section{Site Selection}

I studied three neighborhoods as part of a community-based science project and selected them based on general differences in landscape characteristics and prior community connections. These neighborhoods were Hillsdale, Lents and the Pearl (Fig. 1). Hillsdale, with an area of $\sim 5 \mathrm{~km}^{2}$ is located in Portland's West Hills, about $6.5 \mathrm{~km}$ from downtown. Hillsdale has a relatively high proportion of tree cover within and although it had fewer parks and green spaces, it had greater proportions of undeveloped spaces compared to Lents and Pearl.

The Lents neighborhood $\left(\sim 8 \mathrm{~km}^{2}\right)$ is a suburban neighborhood in Portland, six miles SE of downtown (Fig. 1). Lents is a hub of transportation and industry, with low

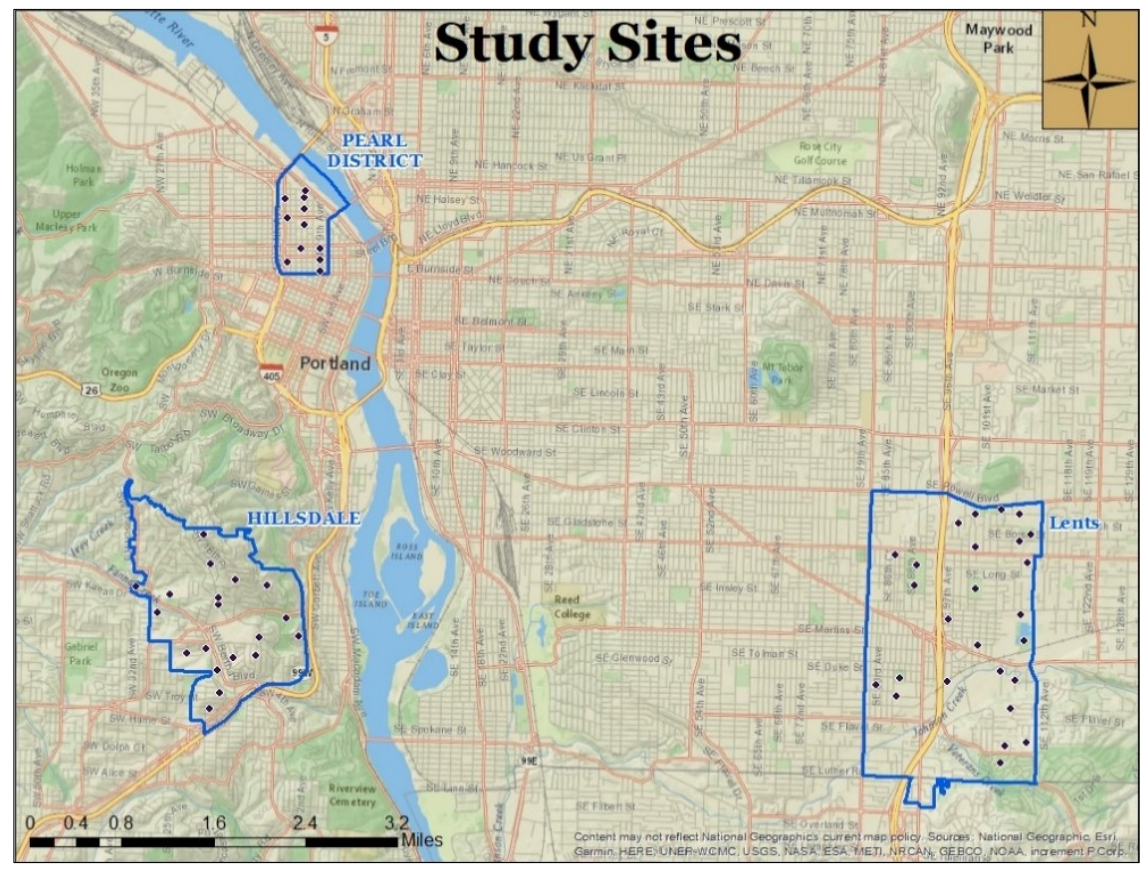

Figure 1: Map of study neighborhoods, dots represent point count stations. Hillsdale is located in Portland's West Hills, Pearl is in the business district, and Lents is a suburb on the East Side of the Willamette River. Basemap from ESRI, ArcGIS. 
levels of tree cover and much connected impervious surface. There are number of parks and green spaces interspersed through the neighborhood. Many of these parks have low levels of plant diversity and habitat structure, with little to no connectivity to other parks.

The Pearl District $\left(1.2 \mathrm{~km}^{2}\right)$ is located just northwest of the downtown city center (Fig. 1). This neighborhood used to be dominated industrial but has been revitalized and now consists of upscale businesses and residences. The Pearl is covered primarily by man-made surfaces, except for the Park Blocks, two city parks and apartment green spaces.

\section{Sampling Methods}

Both neighborhood parks and residential areas in the surrounding neighborhoods were sampled. All parks in each neighborhood (Table 1) were monitored. Residential areas were generated randomly in ArcGIS using the "Create random points" tool. Points placed into inaccessible areas by GIS randomization were snapped to the nearest accessible location, often sidewalks along roads. Residential point count stations were spaced $250 \mathrm{~m}$ apart to ensure the separation of observed individuals. All stations were located at least $80 \mathrm{~m}$ away from large roads and park boundaries (Donnelly \& Marzluff, 2004; Tremblay \& St. Clair, 2011). A total of 61 stations were used, with 53 meeting the criteria for data analysis (Table 1). 
Table 1. Types and counts of stations within each neighborhood. Hillsdale had 2 small parks (Stephen's Creek \& Hillsdale City Park) and 1 large park (George Himes). Lents had 8 parks with 10 total sites; two parks were medium in size (Lents Park and Foster Floodplain) and six were small parks (Beggar's Tick, Bloomington Park, Earl Boyles Park, Ed Benedict Community Garden, Ed Benedict Park, and Glenwood Park). Pearl had four residential sites that were located near apartment complexes in the urban matrix and 6 small park sites (Jamison Park, The Fields, Tanner Springs, and three Park Block segments).

\begin{tabular}{lcccc}
\hline Stations & Residential with & Residential Without & Small Park & Medium \\
& Front Yards & Front Yards & & Park \\
\hline Hillsdale & 12 & 3 & 2 & 1 \\
Lents & 15 & 0 & 6 & 4 \\
Pearl & 0 & 4 & 6 & 0
\end{tabular}

Park stations were sampled based on park size and accessibility. Parks under 10 ha were classified as "small parks" and only had one station located as near to center as trails permitted. There was a total of 14 small parks, two in Hillsdale, six in Lents, and six in the Pearl. Parks over 10 ha were classified as "medium parks" and had two stations randomly placed at least $250 \mathrm{~m}$ apart (Donnelly \& Marzluff, 2004). A total of three medium parks were studied, none of which were in the Pearl. George Himes (13 ha) had only one station as it was divided by a road and only the northern section had access through it. Stations were only located where access was permitted, as many parks had restricted areas to the public (e.g. active restoration spots in Foster Floodplains). Parks in Pearl generally shared a nearest neighbor $<250 \mathrm{~m}$ away from each other, but were separated by a densely urban landscape. 
Parks were further separated into two separate categories: nature parks and recreational parks. Nature parks were defined as parks that had vegetative structure underneath the canopy layer. Recreational parks were parks that lacked vegetative structure underneath the canopy. Recreational parks were multi-use and typically had greater human visitation. All of Hillsdale's parks were defined as nature parks, Lents had three nature parks (Foster Floodplain, Ed Benedict Community Garden, and Beggar's Tick). Pearl had one nature park, Tanner Springs.

Community-based Science

Community-based scientists were recruited starting in March (2018) with the initial training on April 27 (2018). Recruitment was done through posts on social media made by Audubon's Backyard Habitat Program and Green Lents. Further recruitment was done by placing fliers throughout the three neighborhoods and short recruitment presentations at Portland State University classes.

Training was conducted by myself and Dr. Michael Murphy of Portland State University. The initial training went over the project goals of "Bird Count PDX" and subsequently taught volunteers how and when to conduct point counts. Outreach to Bird Count PDX volunteers occurred at least once a month in the form of short reports outlining project progress and initial results. 


\section{Point Counts}

Six participating community-scientists and I conducted counts during the 2018 Spring and Summer breeding season (May 01 - July 31). All birds heard or seen within 50 $\mathrm{m}$ of the point count station were recorded during morning surveys (30 minutes after sunrise and no later than $10 \mathrm{AM}$ ) on days of fair weather (above $50^{\circ} \mathrm{F}$, no rain above a drizzle or wind above a breeze). Each count started with a passive period of observation of seven minutes, followed by a 10 -min count period. Breeding behavior was observed and scored based on an ordinal scoring system (Table 2).

Table 2. Scoring for breeding bird behavior. No breeding behavior exhibited was given a value of zero.

\begin{tabular}{|l|l|}
\hline \multicolumn{1}{|c|}{ Point Value } & \multicolumn{1}{c|}{ Behavior } \\
\hline 1 & Singing male \\
\hline 2 & Singing male with a female present \\
\hline 3 & Bird carrying nest materials \\
\hline 4 & Bird carrying food \\
\hline 5 & Nestling observed \\
\hline
\end{tabular}

Flyovers, incidental observations (those before the start of the 10-minute count or afterward), and unidentified species were recorded, but not used in statistical analyses. Analysis were run on passerine and near passerine species which were expected to utilize the nearby urban habitat structure. Aerial specialists were removed (e.g. swallows) (Fernández-Juricic, 2000). 
Avian foraging guilds, diets, and nesting substrates were determined based on species accounts from The Birds of North America online database (Rodewald, 2015). Species traits were used to observe the dominance of different feeding and nesting strategies between neighborhoods and across a spectrum of anthropogenic disturbance, thus invasive species were included in these comparisons.

Observations were made during weekdays, ensuring that observations were not confounded by possible changes of bird behavior due to changes in human behavior over the weekend (e.g. more or less driving, more people at home, etc.) (Sparks, Huber, \& Tryjanowski, 2008). Site selection was determined randomly each sampling day. The sites with less visitation were pooled and one was randomly chosen each morning. This was the first site sampled for the day. The next station would be the next closest station to the first, and so forth until the end of the sample period, no later than 10:00 hours (Verner \& Ritter, 1986). Each point count station was sampled a minimum of three times over the course of the sampling period. Some stations were sampled up to eight times by community scientists.

\section{Front Yard Vegetation Surveys}

Front yard vegetation structure was measured, and for my purposes, front yards were defined as parts of a yard that were adjacent to a road or sidewalk and not separated by a fence or other built structure. Street trees and city managed green space alongside roads were not measured as they are often not upkept by individual property 
owners, thus they don't reliably reflect decisions made by those living in adjacent homes.

Percent cover of five habitat types (Fig. 2) were visually estimated using a "Nikon laser rangefinder" within each yard using the following scale: (1) OTC: Overstory Tree Canopy, canopy above 9.1m, (2) UTC: Understory Tree Canopy, canopy under 9.1 m, (3) LS: Large Shrub, shrubs above $1.5 \mathrm{~m}$ tall, (4) SS: Small Shrubs, shrubs under $1.5 \mathrm{~m}$ tall, and (5) Ground Cover. Ground Cover was split into three categories: (1) Paved surfaces, (2) Herbaceous Vegetation, which included small ground cover, garden plants, (3) Lawn and (4) Barren Ground which was composed of gravel, bare ground, and bark mulch (Audubon, n.d.).

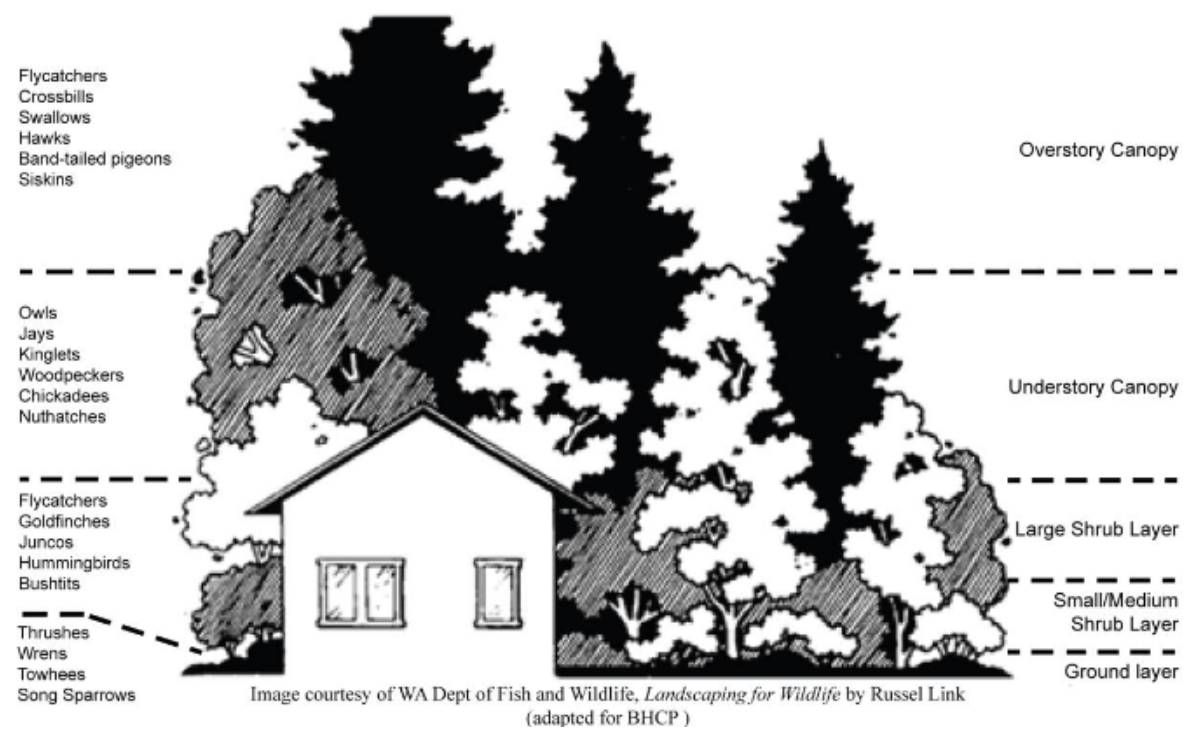

Figure 2. Representation of the five vegetation layers measured in front yards. Overstory Canopy (OTC > $9.1 \mathrm{~m}$ ), Understory Canopy (UTC $<9.1 \mathrm{~m}$ ), Large Shrub Layer (LSL $>1.5 \mathrm{~m}$ ), Small Shrub Layer (SS $<1.5 \mathrm{~m}$ ). Four types of ground layers were measured: lawn, herbaceous vegetation, paved, and barren ground (gravel, bare ground, bark mulch). Picture from Audubon of Portland's Backyard Habitat Program (Audubon, 2019). 
Front yard total habitat cover was estimated in the field using maps generated with ArcGIS. Each point count area had a $5 \mathrm{~m}$ by $5 \mathrm{~m}$ grid overlaid on top of it to estimate percent cover of each habitat type within each yard. For each station total area covered by front yards was calculated and the proportion of yards covered by each habitat layer calculated (Munyenyembe, Harris, \& Hone, 1989).

$\operatorname{ArcGIS}$

I used ArcGIS (ESRI, 2012) to measure landcover traits within buffers surrounding the studied point count stations. Three buffer sizes were used to represent different scales of habitat. A buffer with a radius of $1 \mathrm{~km}$ was used to represent landscape/neighborhood scale habitat (Marzluff, 2001), a buffer with an area of 10 ha (radius $\sim 178 \mathrm{~m}$ ) was chosen to represent the minimum size habitat patch needed to support greater levels of biodiversity than non-green spaces (Fernández-Juricic \& Jokimäki, 2001), and a buffer encompassing only the $50 \mathrm{~m}$ point count area (radius $=50$ m) was chosen to represent the hyper-local environment composed of either park only habitat or residential only habitat (Degraaf, Geis, \& Healy, 1991).

Landcover proportions within each buffer were created using landcover data from EnviroAtlas (Pickard et al, 2015) and the spatial analysis 2 toolset. EnviroAtlas uses first return LIDAR data to create 1-meter resolution land cover data. Land cover types are split into eight categories: (1) Water, (2) Impervious surface, (3) Soil/Barren ground, (4) Grass/Herbaceous, (5) Trees/Forests, (6) Agriculture, (7) Woody Wetlands and (8) Emergent Wetlands. Of these eight, only three were retained: Impervious surface, 
Grass/Herbaceous and Trees/Forests. The other five were dropped as they were seldom or never represented.

ArcGIS park layers were dissolved to be able to sum the area of parks which shared a border. Aggregate polygons was used to combine parks within $20 \mathrm{~m}$ to each other so that they would have a contiguous area. Parks were classified as small $(<10$ ha), medium (10-40 ha) and large (> 40 ha) (Donnelly \& Marzluff, 2004). Distance to nearest park was then classified for each size category using the "near" tool in ArcGIS. Population within each buffer was summarized using the EnviroAtlas "Dasymetric Population for the Conterminous United States" dataset. Populations were estimated using "Zonal Statistics 2" in ArcGIS. Reported values were the total number of people living within the buffer zone. The total number of buildings in each buffer was similarly summed.

\section{Statistical Analyses}

Pooled community statistics were created for each point count station. These were native species richness, mean native abundance, and Shannon's Diversity of native species. Species richness was the total number of species observed over the study. Mean abundance was the total abundance divided by the number of point count station visits. Shannon's Diversity was calculated as $H=-\sum_{i=1}^{S} p_{i} \ln p_{i}$, where the proportion of species $i$ to the total number of species $p_{i}$ is multiplied by the natural log of $p_{i}$ (Shannon \& Weaver, 1948). Native species were focused on as they are often priorities 
for management and are specifically a focus of the Portland Audubon's Backyard Habitat Certification Program (Audubon, n.d.)

Species area relationships were created to test species richness between neighborhoods. Separate species area relationships were created to test species richness between nature parks, recreational parks, and all parks combined. Species accumulation curves were created for each neighborhood, for residential point count stations by neighborhood, and for park types. Accumulation curves represented total species seen by each additional station visit, accounting for disproportionate sampling effort among point count stations.

Separate two-way ANOVAS were conducted for species richness, average abundance, and Shannon's diversity to see if avian communities differed by neighborhood and station type. Alpha values for significance were set as 0.05 , alphas between 0.05 and 0.10 were reported as possible differences. Residual testing was conducted using Levene's test for equal variance and the Shapiro-Wilk test for normality. Assumptions were violated for both average abundance and diversity. To resolve, log (average abundance) was taken and diversity was squared. Tukey's post-hoc test was conducted for pairwise comparisons between neighborhoods.

ANOVAs were used to test if avian feeding guilds, diets, and nesting guilds differed between stations within neighborhoods. These species traits were also tested along the UI across and within neighborhoods. Average abundances (total abundance over the field season divided by number of station visits) was compared between neighborhood stations. Data was log transformed to achieve normal distribution of 
residuals. When normality was not achieved, Kruskal Wallace tests were used in place of ANOVA.

Vegetative layers in front yards were compared between Hillsdale and Lents using t-tests. Pearl was excluded from this analysis as no front yard were present in this neighborhood. Yards were also tested along an Urban Index to see if vegetative characteristics within yards changed as urbanization increased.

I used principal component analyses (PCA) of the landscape variables (1 km radius buffer) surrounding all 53 stations to derive synthetic axes to describe the dominant patterns of variation in landcover and land use across the sampled urban landscape. This PCA was used to visualize differences between land cover, isolation of green spaces, and anthropogenic disturbance, thus it was not used in avian community analysis. The eight variables included in the PCA consisted of the three landcover variables (percent impervious surface, canopy cover and herbaceous vegetation), distance to three different park sizes (small, medium and large) and two variables used to describe level of urbanization (total population and number of buildings). PC1, PC2 were used to plot the PCA as they had the greatest eigenvalues (3.3 and 2.3 respectively) and cumulatively explained $70 \%$ of variance (Jolliffe \& Cadima, 2016). An urbanization index was created for each station using PCA of variables describing urbanization (percent cover impervious, total population and number of buildings) (Pennington \& Blair, 2012). This was done for at the landscape level (1 km radius buffer), an often-used delineation (Lepczyk \& Warren 2012, Marzluff 2001). PC1 explained more variance (74\%) than the often used $70 \%$ cutoff for index creation, thus it 
is included in regression analysis as the "urbanization index (UI)" (Jolliffe \& Cadima, 2016). The UI was highly correlated with all other predictor variables and was kept as the only land predictor at the neighborhood scale. As Hillsdale, Lents and Pearl lie along a continuum of $\mathrm{UI}$, response variables were modeled across all sites using simple linear regression. Regression residual testing was conducted in R using Shapiro-Wilk and Breusch-Pagan (homoskedasticity) tests.

Multiple regression models were created for native species richness, average native abundance, and Shannon's diversity of native species as they are representative of avian communities (Marzluff, 2016). Three scales were tested, a landscape scale (1 $\mathrm{km}$ radius buffer), local scale (10 ha circle centered on station) and immediate scale (50 m point count area $\sim 1 \mathrm{ha})$. The landscape scale ( $1 \mathrm{~km}$ radius buffer) is the recommended neighborhood scale proposed by Marzluff (2001), 10 ha reserve size is the minimum size reserve recommended by (Fernández-Juricic \& Jokimäki, 2001) and the $\sim 1$ ha is the $50 \mathrm{~m}$ point count station, representing the immediate environment.

Information criterion based (AIC) stepwise multiple linear regression models (both forward and backwards) were utilized to select the best model of these relationships ( $\triangle \mathrm{AIC}$ less than or equal to 2). Alpha values were set at 0.1. AIC values from regression models were compared to explore which spatial scale best modeled native species richness, average abundance, and diversity. All independent variables were standardized (z-score), allowing for comparison of regression coefficients. Number of point count station visits were included in all regressions to check if sampling effort impacted avian community statistics. 
The landscape model included two predictive variables: UI and number of station visits. Using UI instead of land cover statistics from LIDAR data eliminated multicollinearity between variables and still captured land cover trends. At the local (10 ha) scale and immediate scale (50 m point counts) multiple regressions were created to explore the relationship between landcover, distance to nearest park, and placement along the UI. Multiple regressions at the local and immediate scales did not suffer from multicollinearity. Independent variables at these scales were percent cover data (impervious surface, herbaceous and canopy cover), human population within the buffer, number of buildings within the buffer, and UI (Pennington \& Blair, 2012; Rodewald, 2012).

Once the best model was determined based on AIC, a full model was created. This full model included human population and the total number of buildings within the buffer and the average abundance of invasive species at each station (total invasive abundance divided by number of station visits).

The same AIC approach was used to model the responses of native species richness, average native species abundance, and native species diversity to stations which were located in suburban residential areas. The best model developed was applied to these to test how predictive it was of residential areas. This model was then compared to a model utilizing the five vegetative layers in front yards as independent variable 


\section{Results}

Neighborhood Landscape Traits

Hillsdale had the greatest proportion of tree cover (44\%) and lowest proportion of impervious surface (35\%). Lents was predominantly impervious land cover (49\%), had the largest proportion of grass and herbaceous land cover (31\%) and the second greatest amount of tree cover (19\%). Pearl was almost exclusively impervious surface (77\%), had some tree cover (6\%), and very little grass and herbaceous cover (3\%). The Pearl neighborhood boundary overlapped the Willamette River ( $14 \%$ land cover) and was the only neighborhood with a large proportion of water.

Based on the landscape characteristics above, and Marzluff et al's (2001) classification standards, levels of urbanization were classified as follows: the Pearl neighborhood as "urban" (percent built $=77 \%$ and population density $=50.2$ people/ha), Lents as highly urban/suburban (percent built $=49 \%$ and population density and 25.4 people/ha), and the highly canopied Hillsdale as suburban (percent built $=35 \%$

and population density $=14.3$

people/ha) (Fig. 3). Note all three

neighborhoods have varying areas

(Hillsdale: $5.21 \mathrm{~km}^{2}$, Lents: $7.85 \mathrm{~km}^{2}$,

Pearl: $1.22 \mathrm{~km}^{2}$ ).

To account for varying

landscape-scale landcover and human

urbanization stations $(n=53)$ were
Table 3. Factor loadings of PC1 and PC2 from PCA of landscape traits.

\begin{tabular}{|lrr|}
\hline \multicolumn{1}{|c}{ Variables } & PC1 & PC2 \\
Distance to Small Park & -0.077 & 0.300 \\
Distance to Medium Park & -0.070 & -0.399 \\
Distance to Large Park & 0.223 & 0.537 \\
\% Impervious Surfaces & 0.529 & -0.110 \\
\% Canopy Cover & -0.510 & -0.173 \\
\% Herbaceous or Grass Cover & -0.211 & 0.556 \\
Total Buildings & 0.343 & 0.232 \\
Human Population & 0.487 & -0.241 \\
\hline Proportion of Variance & 0.418 & 0.285 \\
Cumulative Proportion & 0.418 & 0.703 \\
\hline
\end{tabular}


given a 1-km radius buffer, representing a neighborhood-scale matrix (Marzluff et al., 2001; Rodewald, 2012). Percent land cover was analyzed and an urbanization classification was assigned to each station. Hillsdale had 14 suburban stations and 4 exurban stations, Lents had 14 suburban, 9 urban, and 2 exurban stations, and Pearl had 10 Urban stations (Fig. 3).

PCA of landscape traits in Hillsdale, Lents and Pearl stations indicated that PC1 represented an axis of increasing urbanization; number of buildings, percent impervious surface cover and total population increased to the right of the origin while percent PCA of Neighborhood Landscape Traits

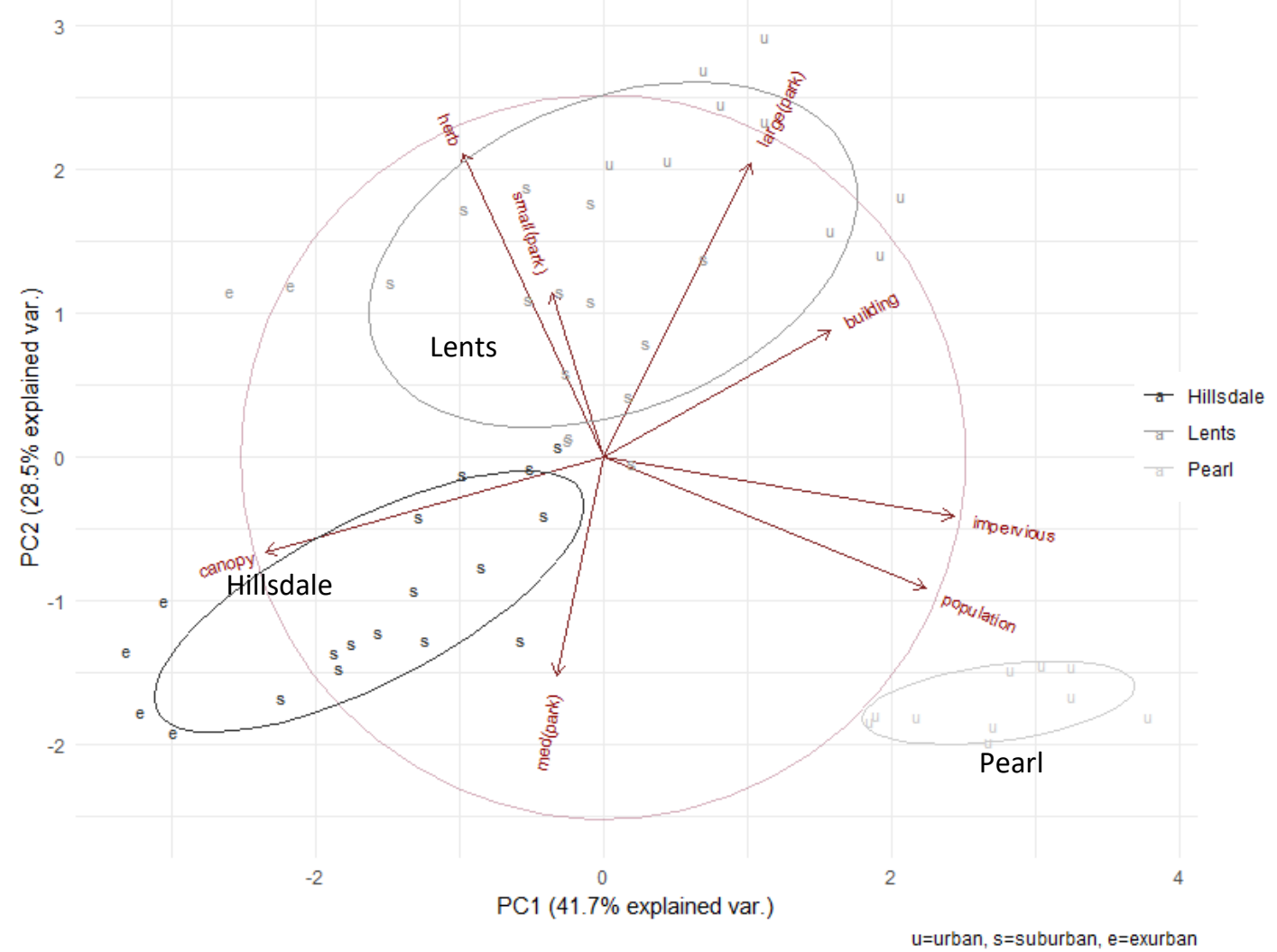

Figure 3. PCA analysis plotting stations based on 8 landscape variables. PCA accounts for $70 \%$ of variability with $P C 1$ describing $41.7 \%$ variability and $P C 2$ describing $28.5 \%$ variability. Pearl plots far to the right along PC1, showing its characteristic urban landscape. Lents plots spread across PC1 and plot far away from medium parks. Hillsdale plots to the left of the origin on PC1 showing that it is the least urban of the neighborhoods. PC2 is dominantly described through distances to medium, small, and large parks and \% herbaceous landcover. 
canopy cover decreased (Table 3). Pearl plots far to the right along PC1 and Hillsdale far to the left, showing the urban nature of Pearl and the large proportion of tree cover in Hillsdale (Fig. 3). PC2 shows positive values above the origin characterized by distance to nearest small park, distance to large park and percent cover herbaceous. Negative PC2 values are related to distance to medium park. Lents stations are differentiated by their nearness to medium and large parks and highly variable proportions of impervious surface cover (Fig. 3).

Principal component analysis of landscape characteristics showed very little overlap between the three neighborhood groupings. Hillsdale, Lents and Pearl illustrate a continuum between urban and suburban classifications. Lents is more highly variable, bridging the highly urban Pearl with suburban Hillsdale. Human disturbance variables (total human population, total number of buildings, and the proportion of impervious surface) for the same $1 \mathrm{~km}$ buffer zones were used to create an urban index (UI). PCA of human disturbance variables returned a PC1 accounting for $74 \%$ of variance and was thus retained as an index (Jolliffe \& Cadima, 2016) (Table 4).

Summary of Bird Observations

Table 4. Factor loadings of PC1 and PC2 from PCA of human disturbance variables. PC1 was retained as a new variable called urban index.

\begin{tabular}{|l|r|r|}
\hline \multicolumn{1}{|c|}{ Variables } & PC1 & \multicolumn{1}{c|}{ PC2 } \\
\hline \% Impervious Surfaces & 0.63 & -0.29 \\
\hline Total Buildings & 0.45 & 0.89 \\
\hline Human Population & 0.62 & -0.25 \\
\hline Proportion of Variance & 0.74 & 0.22 \\
\hline Cumulative Proportion & 0.74 & 0.97 \\
\hline
\end{tabular}

Over the months of May, June, and July, 40 species were observed, four of which were invasive species. A total of 1,802 observations were made, of which 404 were invasive species. Of the 1,802 observations, 13 species (10 native, 3 invasive) accounted 


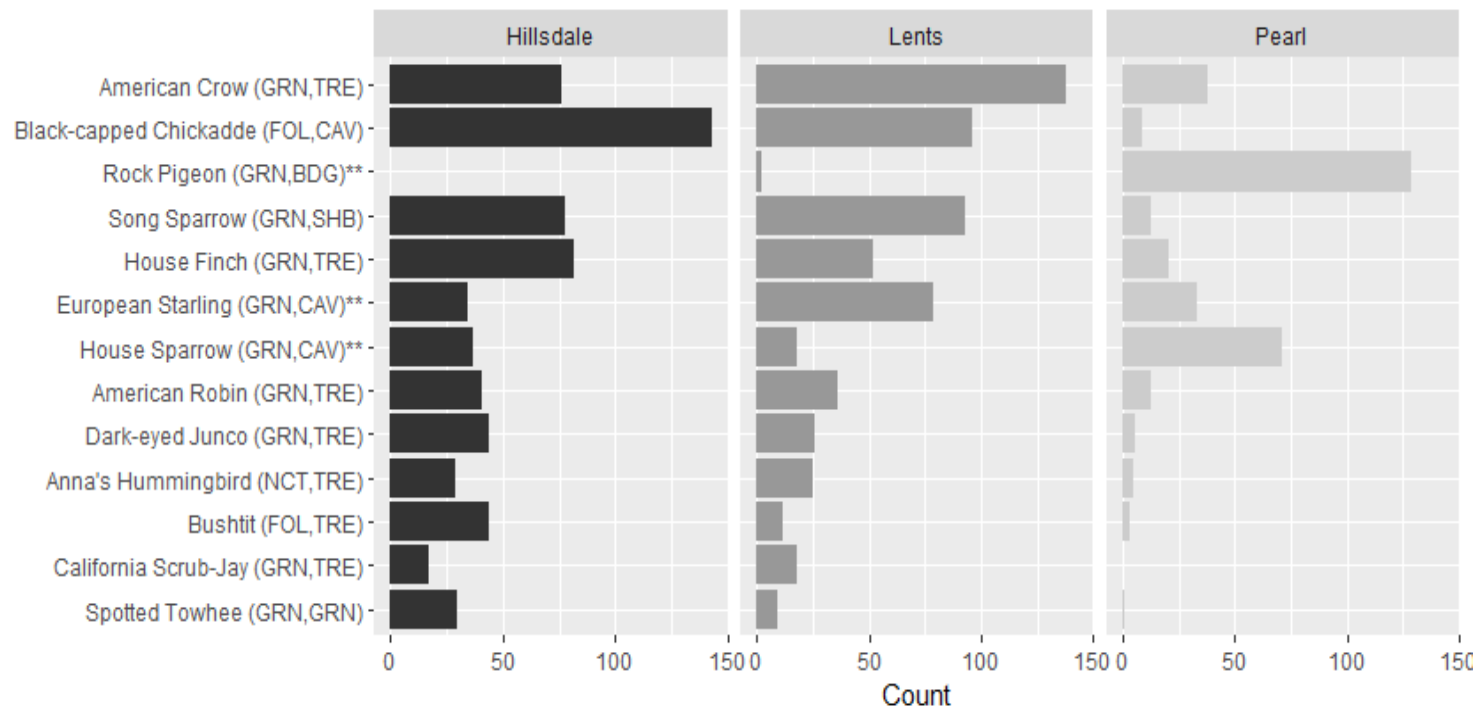

Figure 4. Top 13 most abundant species observed account for $98 \%$ of all observations. A total of 40 species were observed. Species name followed by foraging guild and nesting guild, in that order. Foraging guilds: GRN=Ground, FOL=Foliage, NCT=Nectar. Nesting guilds: TRE=Tree, CAV=Cavity, $B D G=$ Building, $G R N=$ Ground. ${ }^{* *}$ Indicates invasive species. For full list of species observed and life history traits see appendix $A$.

for $\sim 98 \%$ of all observations (Fig. 4). Most of the 13 species were predominantly ground foragers, and all were year-round resident species (Fig. 5). Non-native species were most abundant in the Pearl district.

Of the six observers in this study, two accounted for $90 \%$ of all avian observations. I made $79 \%$ of the observations $(n=1420)$ and a community-scientist accounted for $11 \%(n=206)$. No inter-observer reliability tests were conducted as the majority of stations were monitored by the two of us. We monitored five of the same stations in Pearl, where Rock Pigeons (Columba livia), House Sparrows (Passer domesticus), European Starlings (Sturnus Vulgarus), American Crows (Corvus brachyrhynchos), and House Finches (Haemorhous mexicanus) made up 80\% of the 
total abundance of birds. Having observed similar species from a small species pool in Pearl, I assumed we had reliably similar observations.

Sampling effort was disproportionate by neighborhood due to differences in total geographic area. Species area relationships (SAR) were observed by neighborhood (Fig. 5), larger neighborhoods were sampled more and recorded greater quantities of species. Lents was the largest neighborhood and had a total of 34 species observed, Hillsdale had 28, and Pearl only 18. Species richness in parks did not show a SAR $\left(R^{2}=\right.$ 0.03). Separating park by type showed a possible SAR in nature parks $\left(R^{2}=0.56\right)$, but no SAR in recreational parks $\left(R^{2}=0.01\right)$ (Fig. 6).

Species accumulation curves (SACs) show Lents and Hillsdale have similar species richness by sampling effort, whereas Pearl had fewer species (Fig. 6). SACs show

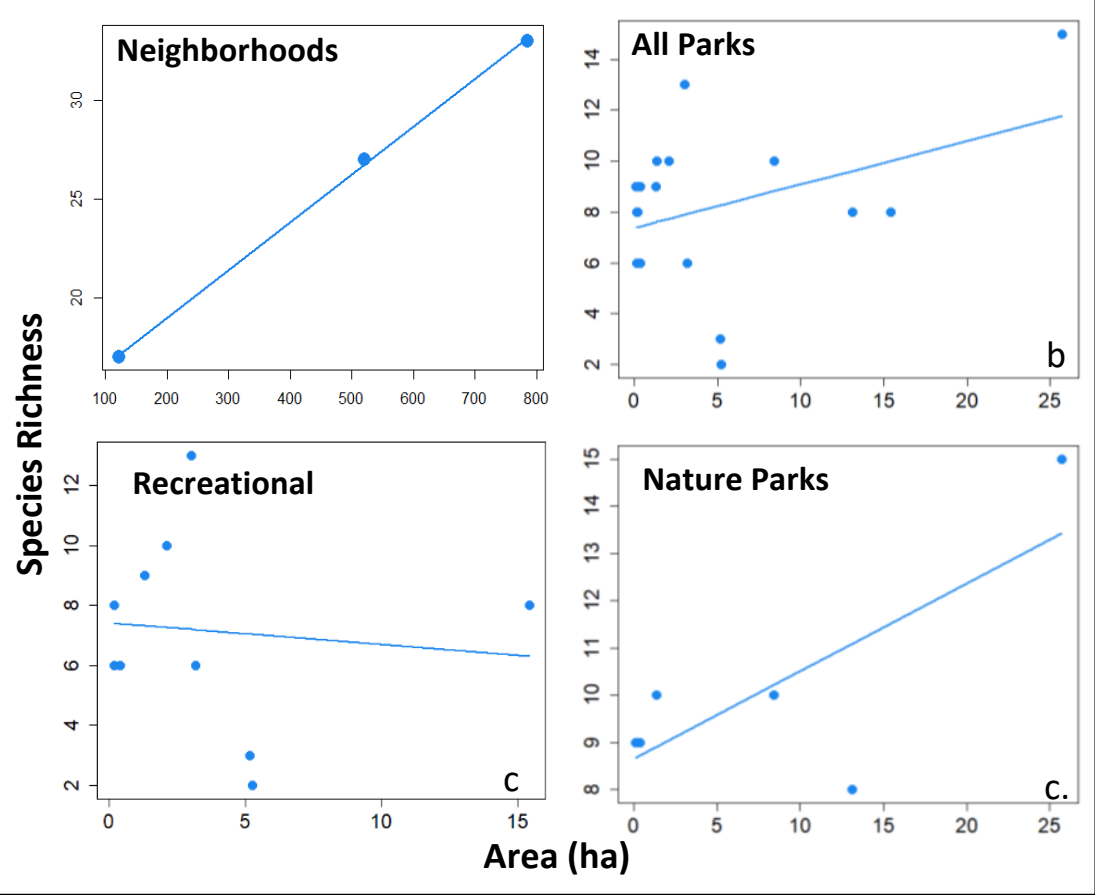

Figure 5. Species area relationships shown for $\boldsymbol{a}$. neighborhoods, $\boldsymbol{b}$. all parks, c. recreational parks, and c. nature parks. The highest species richness was observed in Lents, second in Hillsdale, and least in Pearl 
Hillsdale likely had the most species per residential station, Lents the second most and Pearl the least (Fig. 6). SACs also show nature parks probably had greater species richness than recreational parks (Fig. 6). Rarefaction curves were not generated to account for sampling effort, as trends are clearly observed at the termination of the least sampled accumulation curves (Fig. 6).

Native Species: Differences Within and Between Neighborhoods

Native species richness was not observed to be different by station type $\left(F_{2,48}=1.55, P=0.22\right)$ but it was distinct by neighborhood $\left(F_{2,48}=18.08, P<0.0001\right)$. On average, native species richness was 9.6 ( \pm 2.4) in Hillsdale, $6.6( \pm 2.4)$ in Lents, and 4.5 ( \pm 1.4$)$ in Pearl (Fig. 7).

Diversity of native species was
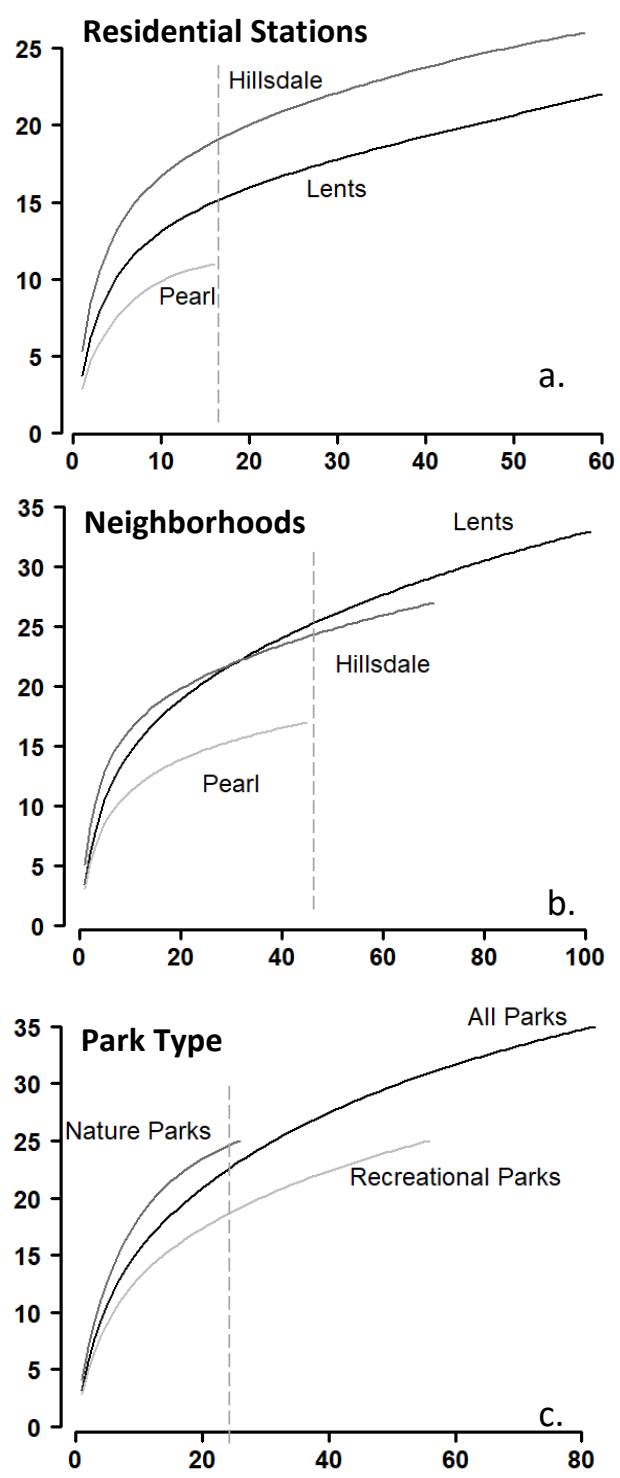

Figure 6. Species accumulation curves depicting species richness by the total count of stations visited. Dashed line shows termination of the curve with the lowest sampling effort. Plot $\boldsymbol{a}$. depicts total species richness by neighborhood, plot $\boldsymbol{b}$. is species richness by residential stations \& plot c. is species richness by park type.

observed to be lower in recreational parks $\left(1.7 \pm 0.3 ; F_{2,48}=3.3, P=0.04\right)$ than in residential sites $\left(1.7 \pm 0.4 ; F_{2,48}=3.34, P=0.44\right)$ but it did not differ between nature 
parks $(1.8 \pm 0.2)$ and residential sites, or between residential sites and nature parks. On average, native diversity was greatest in Hillsdale $\left(2.3 \pm 1.0 ; F_{2,48}=7.7, P=0.001\right)$ but Lents $(2.9 \pm 1.4)$ and Pearl $(3.1 \pm 1.2)$ were not detected to be different from each other $(P=0.31)$.

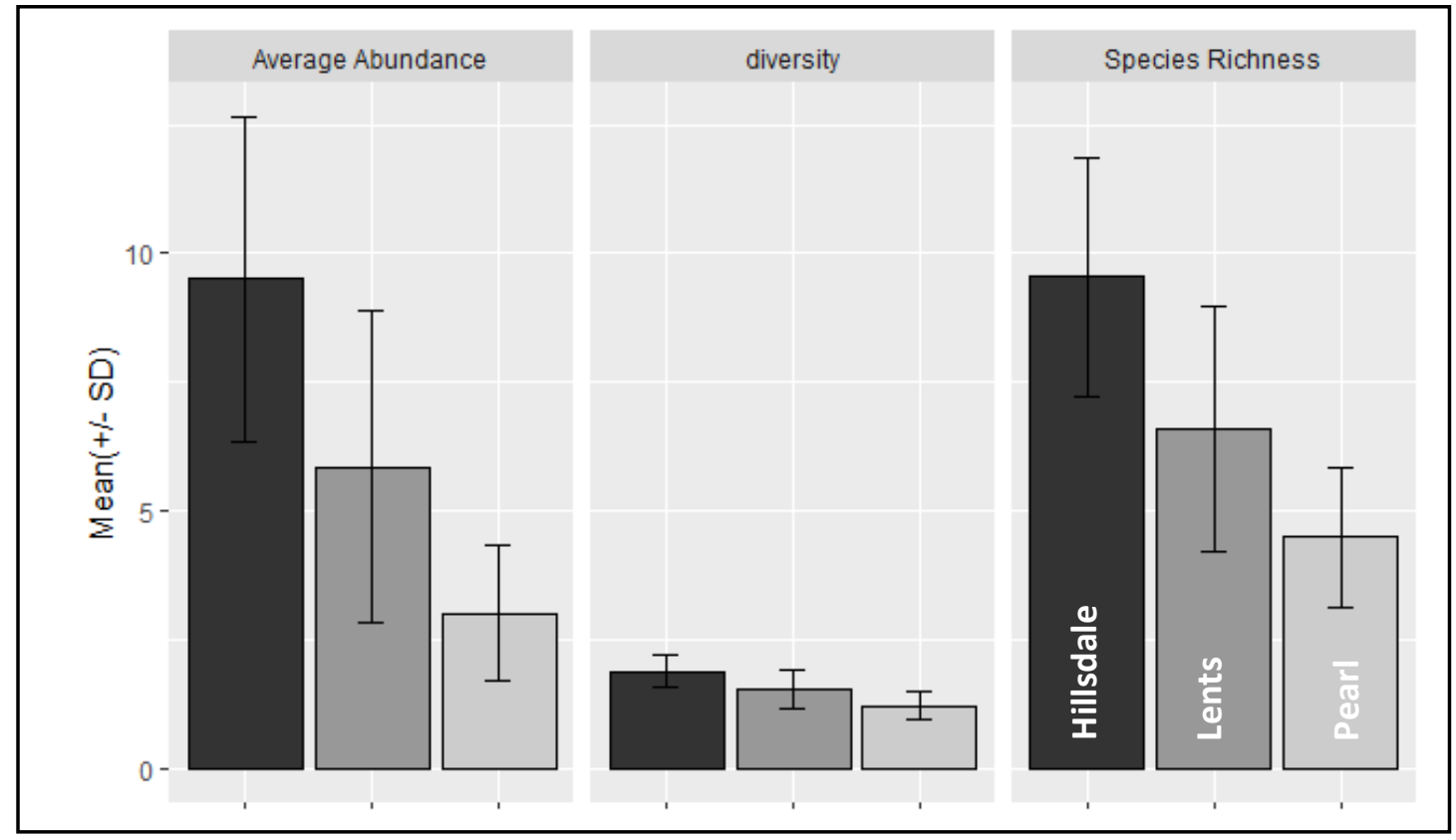

Figure 7. Comparisons of untransformed average abundance, diversity, and species richness between neighborhoods (Hillsdale, Lents, and Pearl). Error bars show standard deviation. Each neighborhood was distinct from all others for average abundance, diversity, and species richness. Average abundance was $9.5( \pm 3.1)$ in Hillsdale, $5.9( \pm 3.0)$ in Lents, and $3.0( \pm 1.3)$ in Pearl. Shannon's diversity was $1.9( \pm 0.3)$ in Hillsdale, in Lents $1.6( \pm 0.4)$, and Pearl $1.2( \pm 0.3)$. Species Richness was greatest in Hillsdale $( \pm 9.56, \pm 2.31)$, Lents had an average of $6.6( \pm 2.4)$, and was lowest in Pearl $(4.5 \pm 1.4)$. Hillsdale is darkest gray, Pearl lightest, Lents intermediate.

Hillsdale had the highest average native species abundance of $(9.5 \pm 3.3)$, Lents was next greatest $(5.9 \pm 3.1)$, and Pearl had the lowest native species abundance $(3.0 \pm$ 1.4; $F_{2,48}=23.08, P<0.0001$ ) (Fig. 7). Nature parks had greater average native species richness $(9.4 \pm 5.2)$ than recreational parks $\left(3.8 \pm 2.2 ; F_{2,48}=3.45, P=0.040\right)$. Residential sites $(6.8 \pm 3.2)$ potentially had lower native species abundance by station when 
compared to nature parks $(9.4 \pm 5.2 ; \mathrm{P}=0.10)$. residential and recreational sites were not detected as having different native abundances $(P=0.59)$.

\section{Avian Guilds}

Foraging guilds, diets and nesting guilds were compared between neighborhoods and along the UI. Differences were only studied between neighborhoods, as station type was shown to have less of an influence on avian community statistics. Both invasive and native species were included in the following analyses.

Five foraging guilds were observed during the study season: bark gleaners, foliage gleaners, ground foragers, nectar feeders, and raptors (Fig. 8). Foliage and ground foraging species were observed the most often out of the five guilds and were analyzed for differences between neighborhoods and along the UI. Anna's Hummingbirds (Calypte anna), the only nectarivore in this study, were observed dominantly in Hillsdale, occasionally in Lents, and only once in Pearl. Bark gleaners followed the same pattern as nectarivores. Both Bark gleaners and nectarivores were omitted from feeding guild analysis because of small sample sizes.

Foliage gleaners were most abundant in Hillsdale stations $\left(F_{2,50}=8.62, P<0.001\right)$ with a mean average abundance of $3.0( \pm 2.5)$. Pearl stations and Lents stations did not have detectable differences in foliage gleaners, each having $1.4( \pm 1.1)$ and $0.6( \pm 0.6)$ respectively $(P=0.41)$. Increasing $U I$ explained $19 \%$ of variance around decreasing foliage gleaner abundance $\left(F_{1,51}=21.74, P<0.0001\right.$, coefficient $=-0.21$ on log 
transformed data). This pattern was repeated only within Lents $\left(F_{1,23}=4.28, P=0.050\right.$, $R^{2}=0.16$, coefficient $\left.=-0.40\right)($ Fig. 8).

Mean ground foragers observed by station were also observed to differ between neighborhoods $\left(F_{2,50}=4.86, P=0.012\right)$. Pearl $(7.6 \pm 3.1)$ and Hillsdale $(6.8 \pm 2.2)$ stations had similarly greater abundances than Lents stations (5.0 \pm 2.4$)$. Mean average abundance of ground foragers was not observed to change along the UI, within or between neighborhoods (Fig. 8).

Three dominant diets were observed in this study: insectivores, omnivores, and granivores (Fig. 8). The following analyses compare means between average station abundances for the three most abundant diets. Carnivores and frugivores were observed rarely during this study and were excluded from analysis. Carnivores were typically found in Parks in Lents $(n=3)$ and were seen once in a Hillsdale residential station. The only frugivore was Cedar Waxwings (Bombycilla cedrorum) and were observed twice in Lents (once in a nature park, once in a residential site) and once in a Pearl recreational park.

Insectivores were most abundant in Hillsdale stations $(5.4 \pm 2.6)$, second most abundant in Lents stations $(3.4 \pm 2.3)$, and least abundant in Pearl stations (1.8 \pm 1.6 ; $F_{2,50}=10.98, P<0.001$ on log transformed data). Increases in UI explained $30 \%$ of decreases in insectivore abundance across neighborhoods $\left(F_{1,51}=21.94, P<0.0001\right.$, coefficient $=-0.22$ ). Again, UI was more explanatory in Lents, explaining $15 \%$ of variation in insectivore abundance $\left(F_{1,23}=4.19, P=0.52\right.$, coefficient $\left.=-0.20\right)$. Similar slopes 
between the regressions show decreasing insectivores in Lents reflect the trend captured across neighborhoods.

Omnivore abundance was greater in Hillsdale stations $(2.0 \pm 1.0)$ when compared to Pearl stations $(0.9 \pm 0.5)$. Lents stations $(1.5 \pm 1.2)$ were not statistically different from either of the other neighborhoods $\left(F_{2,50}=3.99, P=0.025\right)$. Omnivore abundance was not explained by UI across neighborhoods or within Hillsdale. Increasing UI explained $26 \%$ of the variation around increasing omnivore abundance in Lents $\left(\mathrm{F}_{1,23}\right.$

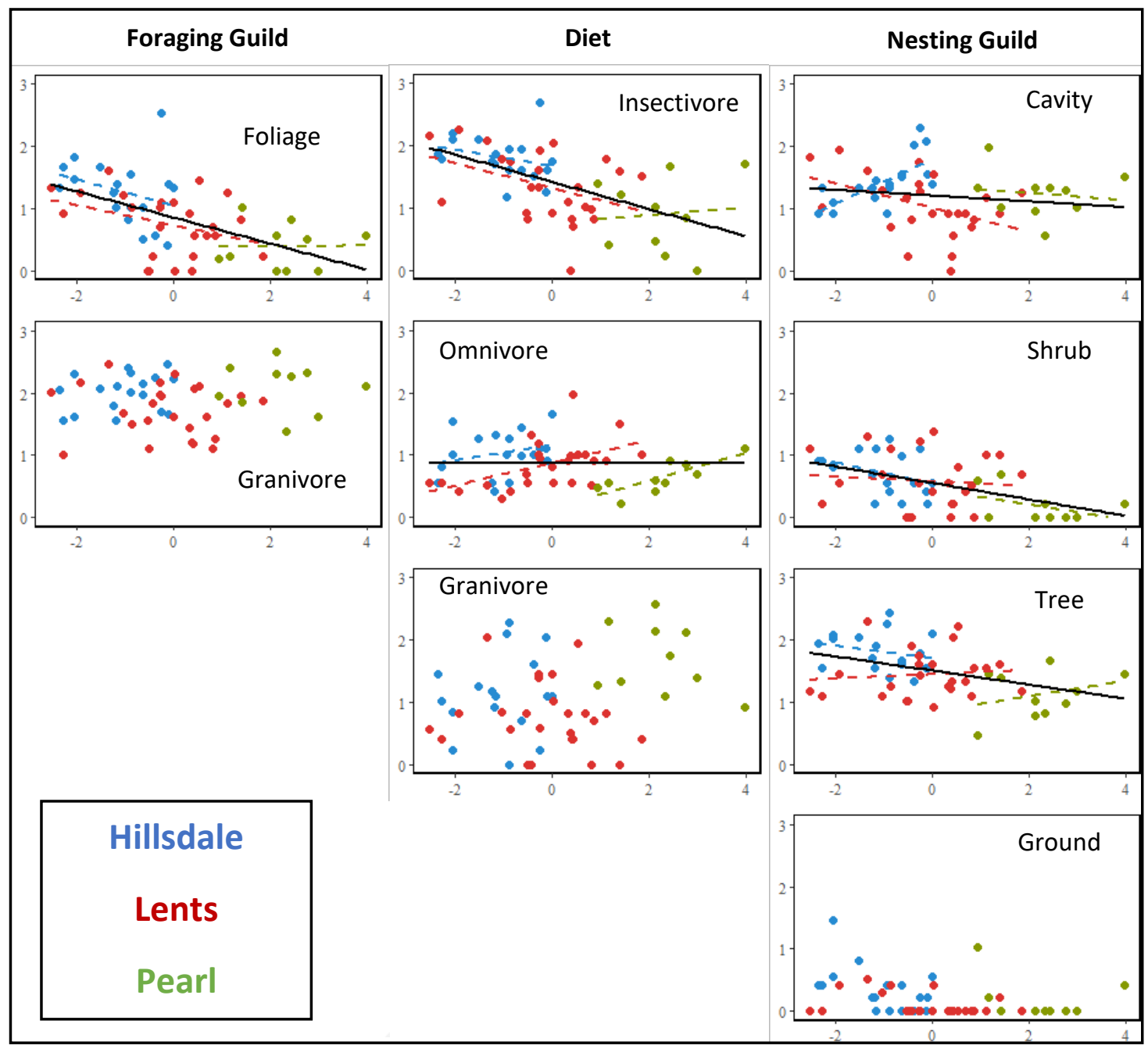

Figure 8. Variations between neighborhoods and along UI for avian foraging guilds, diets, and nesting guilds. Black trendlines show significant relationships across neighborhoods, dashed colored lines show relationships within neighborhoods. 
$=8.27, \mathrm{P}=0.0085$, coefficient $=0.18)$ and in $65 \%$ in Pearl $\left(F_{1,8}=14.79, P=0.0049\right.$, coefficient $=0.47$.

Granivores were most abundant in Pearl stations (5.2 \pm 3.5$)$, whereas Lents stations $(1.5 \pm 1.7)$ and Hillsdale stations $(2.7 \pm 2.5)$ did not differ $\left(F_{2,50}=9.28, P<0.001\right)$. Granivores did not have any significant relationship with UI within or by neighborhood.

Nesting guilds observed in this study were tree, ground, cavity, shrub, building, and parasitic (Fig. 8). Parasitic nesting birds were omitted from analysis as only one was observed, a Brown-headed Cowbird (Molothrus ater) in a Lents nature park (Foster Floodplain). Building nesting birds were also omitted from analysis as the only one in this category was the Rock Pigeon which was observed in great numbers in Pearl, but absent from other neighborhoods. Mean average abundance is reported in the following analyses.

Average cavity nesting birds by station were observed to differ between neighborhoods $\left(F_{2,50}=3.94, P=0.026\right.$ on log transformed data), being greater in Hillsdale stations $(3.5 \pm 2.0)$ than in Lents stations $(2.2 \pm 1.6)$. Pearl stations did not differ on average $(2.7 \pm 1.5)$ from either of the other neighborhoods. Increasing UI did not describe variance around cavity nesting birds but within Hillsdale, increasing UI explained $49 \%$ of the variation around increasing average cavity nesting abundance $\left(F_{1,16}=15.1, P=0.001\right.$, coefficient $\left.=0.36\right)$. An opposite trend was observed in Lents $\left(F_{1,23}\right.$ $=5.14, P=0.033, R^{2}=0.18$, coefficient $\left.=-0.19\right)$, where increasing UI was correlated with decreasing cavity nesting birds. No relationship between UI and cavity nesters was observed within Pearl. 
Shrub nesting birds were observed least in Pearl stations $\left(0.23 \pm 0.37 ; F_{2,50}=\right.$ 4.96, $\mathrm{P}=0.011$ on log transformed data) and similarly in Hillsdale $(1.2 \pm 0.7)$ and Lents $(1.0 \pm 0.9)$. Across neighborhoods, increasing UI explained $22 \%$ of the variance in decreasing shrub nesters $\left(F_{1,51}=14.36, P<0.001\right.$, coefficient $\left.=-0.13\right)$. This pattern was not repeated within any of the neighborhoods, indicating the regression was dominantly detecting differences between neighborhoods.

On average, tree nesting birds were most abundant in Hillsdale stations (5.4 \pm 2.1), second most abundant in Lents stations $(3.5 \pm 2.0)$ and least abundant in Pearl stations $\left(2.2 \pm 1.1 ; F_{2,50}=12.81, P<0.0001\right.$ on log transformed data). Ul was not predictive of tree nesting birds, as it only detected a correlation across neighborhoods $\left(F_{1,51}=9.41, P<0.01, R^{2}=0.16\right.$, coefficient $\left.=-0.11\right)$

Ground nesting birds differed by neighborhood (Kruskal Wallace: $X^{2}=10.15, \mathrm{df}=$ 2, $\mathrm{p}<0.0062)$ with Hillsdale having greater average abundances by station $(0.5 \pm 0.8)$ than Lents $(0.1 \pm 0.2)$. Pearl stations did not differ from either Hillsdale or Lents. Ground nesters could not be tested on the $\mathrm{UI}$ as model residuals were unable to achieve normality.

\section{Yard Characteristics}

Data was collected in front yards in Hillsdale and Lents $(n=27)$ that fell at least halfway within each 50-meter radius station. Pearl, having no front yards was excluded from this analysis. On average, there were 8.2 ( \pm 2.3 yards) front yards within each station, with an average total front yard area of $1,545 \mathrm{~m}^{2}\left( \pm 565 \mathrm{~m}^{2}\right)$. Hillsdale $(n=12)$, 
had similar quantities of front yards per station compared to Lents, 8.0 yards per station $( \pm 1.78)$ and 8.3 yards per station $( \pm 2.6)$ respectively. Cumulative front yard area was also similar by neighborhood, Hillsdale had an average of $1685 \mathrm{~m}^{2}\left( \pm 616 \mathrm{~m}^{2}\right)$ and Lents $1433 m^{2}\left( \pm 492 m^{2}\right)$.

Differences in percent of vegetative above ground cover were observed by neighborhood. On average, overstory tree canopy covered a greater percent of front yard area in Hillsdale $(24.82 \pm 10.59)$ than in Lents $\left(13.77 \pm 10.07 ; t_{23.16}=2.75, P=\right.$ 0.011). Understory tree canopy was greater in Hillsdale $(17.02 \pm 8.02)$ than in Lents $\left(11.14 \pm 6.21 ; t_{20.38}=2.09, P=0.050\right)$. Large shrubs covered $23.23 \%( \pm 10.34)$ of front yards in Hillsdale compared to $12.23\left( \pm 6.11 ; \mathrm{t}_{24.59}=3.64, \mathrm{P}=0.0013\right.$ on log transformed data) in Lents. Hillsdale also had a greater percent $\left(t_{19.37}=2.59, P=0.018\right)$ of small shrub coverage compared to Lents, with averages of $21.93( \pm 9.29)$ and $13.68( \pm 6.68)$ respectively.

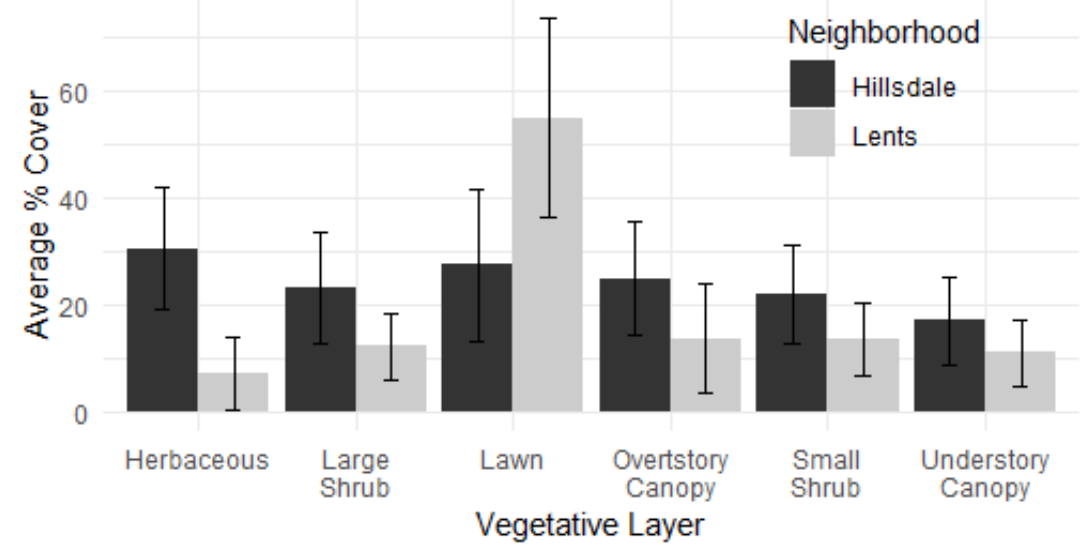

Figure 9. Average proportion of all stations' vegetative cover by neighborhood. Error bars show \pm one standard deviation. 
Above-ground foliage height diversity was calculated using Shannon's diversity index for four vegetation layers: overstory tree canopy (OTC), understory tree canopy (UTC), large shrub layer (LSL), and shrub layer (SL). Average foliage height diversity (FHD) across all sites was $1.2( \pm 0.12)$. Hillsdale had similar FHD $(1.31 \pm 0.07)$ compared to Lents (1.25 \pm 0.14 ) (Fig. 9).

Ground cover was significantly different between Hillsdale and Lents. Herbaceous vegetation was greater, on average in Hillsdale $(30.58 \% \pm 11.55)$ than in Lents $\left(7.37 \% \pm 6.79 ; t_{16.92}=6.16, P<.0001\right)$. As herbaceous vegetation decreased, lawn cover tended to replace it. Hillsdale on average had less lawn cover than Lents, with $27.41 \%( \pm 14.92)$ and $54.92\left( \pm 18.61 ; \mathrm{t}_{24.98}=-4.34, \mathrm{P}=0.00021\right)$, respectively.

Residential suburban stations were used to investigate trends in cumulative front yard characteristics along the UI. Hillsdale and Lents had similar average quantities of front yards per station, but the quantity of front yards within stations increased as UI increased $\left(F_{1,25}=7.87, P=0.0096, R^{2}=0.24\right)$. Increasing yards per station along UI was observed within Hillsdale $\left(F_{1,10}=12.19, P=0.0058, R^{2}=0.50\right)$, but not in Lents. Total area covered by front yards was not observed to change along the UI.

Above-ground vegetative characteristics were seen to be different between neighborhoods, but not to follow a trend along the UI. Lack of trends along the UI indicates above-ground vegetation is mainly a neighborhood effect, not a landscape dependent flux.

Herbaceous ground cover decreased $\left(F_{1,25}=7.05, P=0.014, R^{2}=0.22\right)$ and lawn cover increased $\left(F_{1,25}=5.36, P=0.029, R^{2}=0.18\right)$ as residential sites became more 
urban. Neither Hillsdale or Lents showed a trend of decreasing herbaceous cover or increasing lawn when examined individually, indicating differences are dominantly due to neighborhood effects.

\section{Regression Models}

Regression models were built with landscape factors from three different scales, to assess which predicted native avian community characteristics (species abundance, richness, and diversity) best. All models were significant (Appendix B). Landscape and Local scale models best predicted avian community statistics. Local scale multiple regressions were the most predictive of native species abundance $\left(F_{2,50}=16.07, p<\right.$ $0.0001, R^{2}$ adjusted $\left.=0.37\right)$, richness $\left(F_{5,47}=8.855, p<0.0001, R^{2}\right.$ adjusted $\left.=0.43\right)$, and Shannon's diversity $\left(F_{3,49}=10.65, p<0.0001, F^{2}\right.$ adjusted $\left.=0.36\right)($ Table 5$)$.

Models were tested within each neighborhood, checking to see if the models across neighborhoods were reflected by neighborhood. Of all the models, it was found that $\mathrm{UI}$ in the regional model was the only significant within neighborhood model, explaining varying diversity between Hillsdale stations $\left(F_{1,16}=4.233, P=0.054, R^{2}=\right.$ $0.21)$. Species richness variability was best explained $\left(F_{2,22}=3.45, P=0.048, R^{2}\right.$ adjusted $=$ 0.17 ) by number of station visits (coefficient $=1.11, \mathrm{P}=0.022$ ) and $\mathrm{UI}$ (coefficient $=-$ $1.01, P=0.13)$. In general, patterns across neighborhoods did not repeat within each neighborhood, indicating landscape models are mostly explaining differences by neighborhood. 
Having determined which scale best described avian communities, three more variable types were added to form the full model: Urban Index (UI), distance to parks (small, medium, and large), and the average abundance per station of avian invasive species. UI was included in the model to describe the large-scale landscape variable influence of urbanization (each $10 \mathrm{ha}$ circle accounts for only $3.1 \%$ of the $1 \mathrm{~km}$ circle used to determine UI). The full model (Table 6) accounted for more of the variation than the partial medium-scale model. Almost half of the variability in native species abundance was accounted for by distance to large parks, the amount of impervious surfaces, and the abundance of invasive species $\left(F_{2,50}=14.53, p<0.0001, R^{2}\right.$ adjusted $\left.=0.44\right)$. Variation in richness among stations was attributed to seven variables (number of visits, UI, percent herbaceous and grass cover, percent impervious surfaces, distance to large parks, invasive species, and number of buildings) that in total accounted for nearly half the variation $\left(F_{5,47}=9.72, P<0.001, R^{2}\right.$ adjusted $\left.=0.46\right)$. Highest diversity attributed to lower levels of impervious surfaces, lower UI, less herbaceous and grass cover, fewer buildings, and lower abundances of invasive species $\left(F_{5,47}=9.72, p<0.0001, R^{2}\right.$ adjusted $=$ 0.40) (Table 6). The full model of local-landscape variables includes too many variables to run by neighborhood, but it is very likely that variance explained by the model is due to differences between neighborhoods. 
Stations were subsampled to include only residential stations which contained front yards. Vegetative layer models for residential stations only included percent cover at the five vegetation layers and number of station visits as independent variables.

Native species richness, average abundance, and diversity increased as the percent of

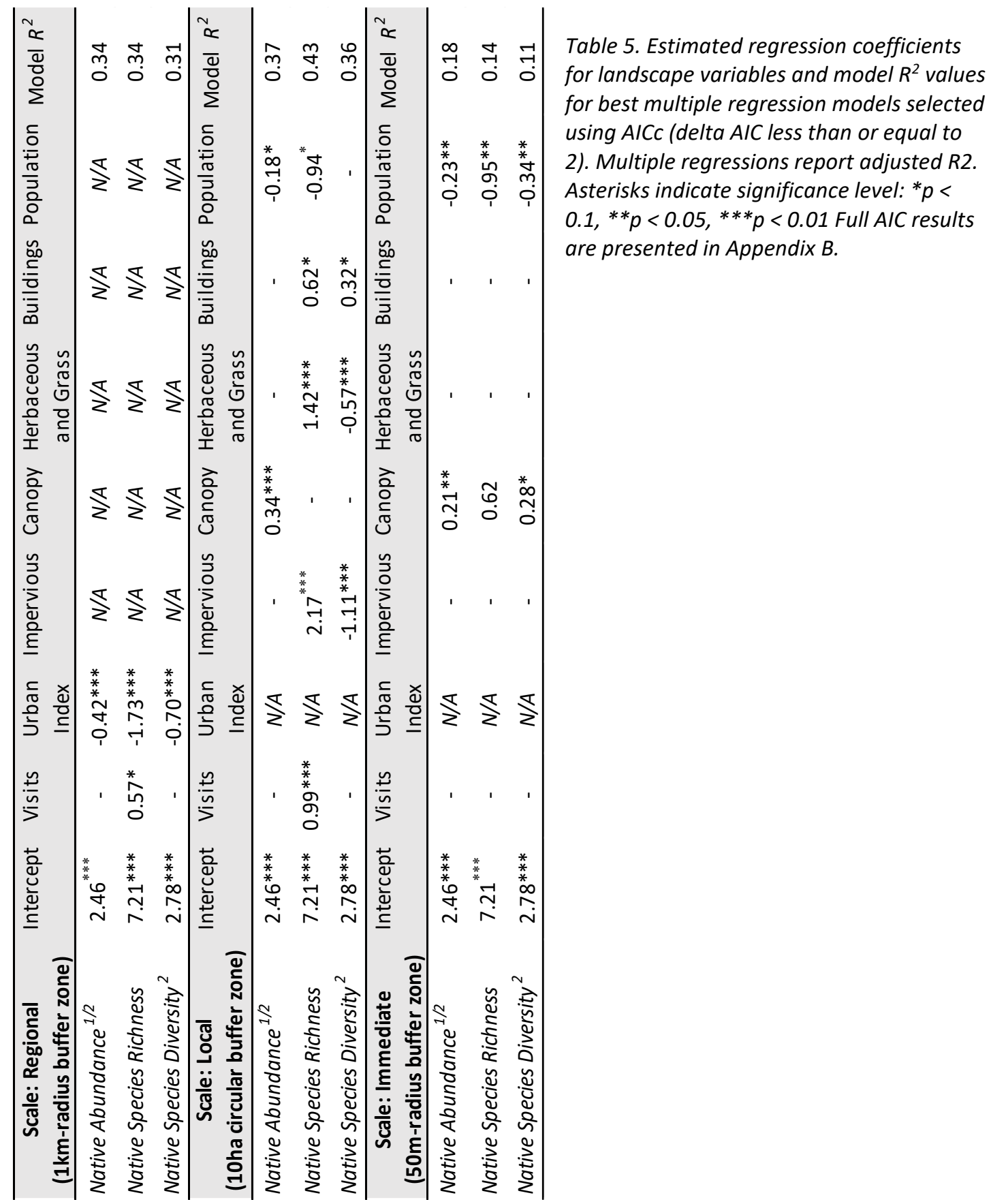


herbaceous ground cover increased (richness: $F_{1,25}=25.84, P<0.0001, R^{2}=0.51$;

abundance: $F_{1,25}=8.78, P<0.01, R^{2}=0.26$; diversity: $F_{1,25}=21.01, P<0.001, R^{2}=0.46$ ) (Table 7).

As 10 ha land cover was shown to best predict avian communities, this scale of land cover characteristics was applied to observations made in residential stations.

Regression models used 10 ha landcover data to create models for all stations sampled. These were shown to significantly predict species richness $\left(F_{1,25}=28.97, p<0.0001\right.$, $R^{2}$ adjusted $\left.=0.54\right)$, average abundance $\left(F_{1,25}=20.98, p<.001, R^{2}\right.$ adjusted $\left.=0.46\right)$, and Shannon's diversity $\left(F_{1,25}=16.62, p<0.001, R^{2}=0.38\right)$ (Table 7$)$. The yard-only model is no better than the 10 ha model at predicting species richness or abundance. However, it better explains variance around species diversity (Table 7).

Table 6. Full model of local-landscape variables (10ha area centered on each station). Estimated regression coefficients shown for landscape variables along with model $R^{2}$ values for best multiple regression models selected using AICc (delta AIC less than or equal to 2). Multiple regressions report adjusted R2. Asterisks indicate significance level: ${ }^{*} p<0.1,{ }^{*} p<0.05,{ }^{* *} p<0.01$ Full AIC results are presented in Appendix $B$.

\begin{tabular}{|r|ccc|}
\hline \multicolumn{2}{|c|}{ Full Model: Local (10 ha circular buffer) } & & \\
Native & Native Species & Native Species \\
Intercept & Abundance & Richness & Diversity $^{2}$ \\
Visits & $2.46^{* * *}$ & $7.21^{* * *}$ & $2.78^{* * *}$ \\
Urban Index & - & $1.19^{* * *}$ & - \\
Herbaceous and Grass & - & & $-0.45^{* *}$ \\
Impervious & $-0.30^{* * *}$ & $-1.28^{* *}$ & $-0.74^{* * *}$ \\
Distance to Large Park & $-0.23^{* * *}$ & $-1.27^{* * *}$ & - \\
Population & - & $-1.08^{* *}$ & - \\
Buildings & - & $0.69^{*}$ & $-0.35^{* *}$ \\
Invasive Species & $-0.19^{*}$ & & \\
Model $R^{2}$ & 0.44 & 0.46 & 0.40 \\
\hline
\end{tabular}


Yard models were created for individual neighborhoods to check if the models across neighborhoods were detecting neighborhood differences, not differences among all residential yards. Regression models using backward selection methods (Gotelli \& Ellison 2013) were created for each neighborhood using the same predictive variables. Despite significant models across neighborhoods, no model within neighborhoods returned a predictive relationship. This lack of within-neighborhood trends suggests my UI analysis for residential stations is mostly detecting herbaceous ground cover trends between Hillsdale and Lents.

Table 7. Models predicting avian community traits in residential areas with yards. Two models were created to compare the influence of vegetative structure with landscape characteristics at the local scale. Estimated regression coefficients shown for landscape variables along with model $R^{2}$ values for best multiple regression models selected using AICc (delta AIC less than or equal to 2). Multiple regressions report adjusted $R 2$. Asterisks indicate significance level: ${ }^{*} p<0.1,{ }^{* *} p<0.05,{ }^{* * *} p<$ 0.01 Full AIC results are presented in Appendix B. Yard vegetative model included six independent variables: overstory and understory canopy, large and small shrub layers, herbaceous ground cover, and number of station visits. Yard landscape model included six independent variables: nearest large park, percent herbaceous and or grass cover, total human population, UI, average abundance of invasive birds, and number of station visits.

\begin{tabular}{lcccccc}
\hline \multicolumn{1}{c}{$\begin{array}{c}\text { Yard Model: } \\
\text { Vegetative Layers }\end{array}$} & Intercept $\begin{array}{c}\text { \% Overstory } \\
\text { Canopy }\end{array}$ & $\begin{array}{c}\text { Understory } \\
\text { Canopy }\end{array}$ & $\begin{array}{c}\text { L Large } \\
\text { Shrub }\end{array}$ & Herbaceous & Model $R^{2}$ \\
\hline Native Abundance & $7.43^{* * *}$ & - & - & - & $1.54^{* * *}$ & 0.26 \\
Native Species Richness & $8.22^{* * *}$ & - & - & - & $1.82^{* * *}$ & 0.51 \\
Native Species Diversity & $0.20^{* * *}$ & - & - & - & $0.20^{* * *}$ & 0.46 \\
\hline \multicolumn{1}{c}{ Yard Model: } & Intercept & Distance to & - & - & - & \multirow{2}{*}{ Model R ${ }^{2}$} \\
Landscape Characteristics & & Large Park & - & & & 0.47 \\
\hline Native Abundance & $7.44^{* * *}$ & $-1.42^{* * *}$ & N/A & N/A & N/A & 0.54 \\
Native Species Richness & $8.22^{* * *}$ & $-1.87^{* * *}$ & N/A & N/A & N/A & 0.38 \\
Native Species Diversity & $1.81^{* * *}$ & $-0.19^{* * *}$ & N/A & N/A & N/A & 0.38 \\
\hline
\end{tabular}




\section{Discussion}

Portland's predicted future level of expansion poses major threats to urban wildlife, as urban development is associated with some of the highest observed rates of species extirpation (Czech, Krausman, \& Devers, 2000). I sought to fill a knowledge gap in the current understanding of urbanization and bird communities in Portland, OR, as only one published study is known to investigate this (Hennings \& Edge, 2003). My research monitored avian communities in three neighborhoods: Hillsdale, Lents, and Pearl. That neighborhoods had different landscape characteristics enabled us to observe the ways which native bird richness, abundance, and diversity changed in response to varying sizes of urban green space, residential front yard characteristics, and surrounding landscape variables. This study explored differences between neighborhood landscape characteristics and associated bird communities. Further, I explored the possibility that collectives of yards may host similar bird communities to small suburban green spaces.

\section{Landscape Characteristics}

The three neighborhoods were quite different in terms of landcover characteristics. Both Hillsdale and Lents are suburban neighborhoods but differ in terms of total developed land. Pearl is almost exclusively developed and is located in the city center. Hillsdale and Pearl embody two extremes of suburban to urban development within my study. Hillsdale has minimal variation in landcover and anthropogenic variables (population and building counts), trending towards high canopy cover and low 
human disturbance. On the other end of the spectrum is the Pearl, dominantly paved with dense human populations and high building counts. Bridging these two neighborhood characteristics is suburban Lents, with some minimally urbanized stations, some very urban stations, and many stations spanning a spectrum between. Total yard area made up an unknown portion of landcover within each neighborhood. This study did not examine the total proportion of each neighborhood that was yard, but future studies should investigate the total amount of space occupied and planted by yards. It was observed that on average, yards in Hillsdale contained more herbaceous ground cover, shrubs, and canopy layers than yards in Lents, which were dominantly lawn.

\section{Avian Trends}

Overall, Pearl was observed to have fewer species than the other neighborhoods studied (Fig. 6). Lents and Hillsdale likely support similar avian species (Fig. 4), but due to disproportionate sampling effort, rarer (for these two neighborhoods) species were observed in Lents. On average, stations in Pearl had the lowest native bird richness, abundance, and (along with Lents) the lowest native species diversity. Between the two suburban neighborhoods, Hillsdale had greater native bird diversity, abundance, and richness by station, than Lents.

The general trend of Hillsdale stations having greater avian community statistics, by station, and Pearl the least, mirrors how developed the neighborhoods are. Though these differences were detected, they seem to be mostly due to differences in species 
abundance. The fact that 13 species comprised $98 \%$ of all observations shows that all three neighborhoods, in general, were not able to support many native species. This is despite any landscape or local differences in landcover type, isolation from parks, or anthropogenic disturbances.

The variation in native species communities was further explored in regression testing, using an urbanization index (UI) created from variables associated with anthropogenic disturbance. This approach was taken as many urban gradient studies have shown declining species richness paired with increasing urbanization (e.g. Pennington \& Blair, 2012; Rodewald, 2012). Across neighborhoods, increasing UI predicted declines in native species richness, abundance, and diversity but for the most part it was not predictive within neighborhoods. Only native bird diversity was shown to decrease with increasing UI values. This lack of correlation within neighborhoods may indicate that localized changes in urbanization are not as important as regional and local landcover types and patterns. It may also indicate that the species seen in this study did not vary enough between neighborhoods to make large differences in the regression models. I attribute this to having studied individual neighborhoods which clustered in urban and suburban zones, not capturing a true rural-urban gradient.

Though yard vegetative structure did not predict species community attributes, a study of yards participating in the Portland Audubon Society's Backyard Habitat Certification Program, Gibbs (2018) found that bird abundance, richness, and diversity decreased with urbanization and increased with greater amounts of tree canopy, shrubs, and herbaceous cover (Gibbs, 2018). Gibbs (2018) found evidence that 
individual yard practices can positively affect avian diversity, but likely not as strongly as regional landscape variables. Further, a study examining aggregated yards in the Chicago-area showed that characteristics of groups of neighboring yards were more important than environmental characteristics at a neighborhood or landscape scale (Belaire et al., 2014). I believe that my results did not reflect these trends as I did not have measurements of backyard vegetation or more than two neighborhoods with yards. Future studies should explore the rich possibilities of LIDAR data, its ability to calculate foliage height diversity and landscape heterogeneity, and its ability to determine yard size (Clawges, Vierling, Vierling, \& Rowell, 2008).

Within neighborhoods the major observed trend was that recreational parks, on average, had lower species diversity and average bird abundance than nature parks and residential sites. The fact that species richness was not detected as different within recreational parks indicates that lower diversity values were likely because of more homogenous bird communities. Increased anthropogenic disturbance in small multi-use parks have been proposed as reasons for low species richness (Fernández-Juricic, 2000). Residential sites and nature parks were seen to have similar native community attributes to each other. This similarity has two major implications: first, residential sites are not the lowest quality patch within an urban matrix, and second, small nature parks are not enough to increase species richness in our cities. In the Chamberlain et al (2007) study it was found that small parks (>1ha) had greater species richness when more adjacent gardens were present. They proposed that the gardens acted to increase the 
footprint of small parks. This indicates that we should focus our efforts on increasing the footprint of functional green space within urban areas.

Interestingly, species area relationships were not detected across parks. I

propose that this is because there is only the urban adaptive pool of 13 species present to utilize the parks within my study neighborhoods. In a study of London parks, Chamberlain et al (2007) found that park area was the most significant variable positively related with species richness. In a study of Seattle's metropolitan area, larger reserves were found to contain richer and more even bird communities (Donnelly \& Marzluff, 2004). Further, reserves larger than 42 ha had more native birds associated with native forest habitat, even when surrounded by $>40 \%$ urban land cover (Donnelly \& Marzluff, 2004). Donnelly and Marzluff's (2004) suggested cutoff of 42 ha in an urban zone was not close to being reached in my study sites, making it unsurprising that I did not see any drastically different communities within parks.

Avian guilds varied across neighborhoods and within neighborhoods depending on placement along the derived UI. Though the same small pool of species utilized my three study neighborhoods, certain guilds tended to be associated with specific inneighborhood urbanization levels. For instance, insectivorous foliage gleaners, such as Black-capped Chickadees, decreased in abundance as overall neighborhood urbanization increased, a pattern mirrored within Lents for both guild and diet. Omnivorous birds were not different, on average, between neighborhoods, but their abundance increased in as a neighborhood's UI increased. This increase reflects their urban adaptivity and generalist diet (Rodewald, 2012) 
Cavity nesting birds did not follow a discernable pattern across neighborhoods, as Lents had the least abundance by station and Pearl and Hillsdale had no detected difference. Within Hillsdale, cavity nesting abundance increased with UI, possibly reflecting the increase in cavity nesting invasive species with $U I\left(F_{1,16}=4.07, P=0.06, R^{2}\right.$ $=0.20$, coefficient $=0.14$ on power regression) . In Lents, cavity nesting abundance decreased as UI increased.

Changes in foraging guilds and avian diets show that native bird communities are composed of more generalist species in the neighborhoods with greater levels of local urbanization. in some cases, this trend is even expressed along a gradient within individual neighborhoods in this study. Increases in generalist species and declines in insectivores along an urban gradient were observed by Rodewald (2012). Vignoli et al (2013) found that nesting guilds also changed along the urban gradient, noting decreases in ground nesting birds and increases in artificial anthropic cavity nesters. This study saw a lack of ground nesting birds outside of Hillsdale and "building" nesting birds dominating Pearl, mirroring the trends seen by Vignoli et al (2013).

Invasive species

Invasive species were a large proportion of species observations in my study. Rock pigeons were the third most abundant species, European Starlings the sixth most abundant, and House Sparrows the seventh most abundant. As invasive species tend to be adapted to exploit urban environments, it is hard to say with certainty if they influence native bird richness and diversity. If invasive birds outcompete native birds for 
limited resources, they would be directly influencing native species communities and not just filling empty niches. Compelling evidence is found when predicting average native species abundance by average invasive species abundance. Simple linear regression explains $47 \%$ of variance around declining native abundance $\left(F_{1,16}=13.92, P\right.$ $=0.0018$, coefficient $=-11.6)$ in Hillsdale and $36 \%\left(F_{1,8}=4.43, P=0.069\right.$, coefficient $=-$ $5.05)$ in Pearl. No trend was observed in Lents

Newton (1994) found evidence that cavity nest sites are limit in urban environments. When nest boxes were provided, they were often occupied in the same year, increasing the breeding density of cavity nesting birds. In following years, the breeding density remained elevated, indicating available cavities were a limiting resource. It is possible that Starlings and House Sparrows (the two invasive cavity nesters in this study) are outcompeting native cavity nesting birds for limited nest sites. Though this could be occurring, it is unlikely in the three studied neighborhoods, as Black-capped Chickadees (Poecile atricapillus) are the only abundant native cavity nester, using cavities too small for European Starlings, the only strict invasive cavity nesting bird observed (Sedgwich \& Knopf, Fritz, 1990). House Sparrows were also abundant, but are known to nest on built structures (Rodewald, 2015).

\section{Lents: A Case Study}

Lents was the most highly sampled station in my study and had the most thoroughly sampled variety of station types. In addition, Lents had stations ranging from exurban to urban classification, providing its own localized gradient of urbanization 
(Marzluff et al., 2001). The high percentage of impervious land cover ( $50 \%)$ and moderate amount of herbaceous land cover ( $30 \%)$ show that Lents has a highly urbanized and developed urban matrix. Being a major hub of transportation and industry, Lents also has high levels of anthropogenic disturbance within the matrix. Despite where stations were within Lents, native species richness and diversity tended to be lower than in Hillsdale. This is best explained by the surrounding, more developed matrix.

Though no non-residential matrix stations were studied in Lents, recreational parks may reflect the matrix well, as they were shown to have lower diversity than nature park and residential sites. Diversity being greater in both nature parks and residential sites shows that they had more even and abundant avian communities. Further, avian communities lost more specialist guilds and gained generalist species as urbanization increased. Foliage gleaners, insectivores, and cavity nesting birds became scarcer while omnivores became more abundant.

\section{Future Studies}

My ability to make strong, definitive statements is limited by the fact that only three neighborhoods were studied; I likely missed fine-grained details as to how urban landscape traits affect native bird diversity. Further, this research was short term and purely observational. A longer-term study would be able to see how already studied communities respond to changes in anthropogenic disturbance. Also, manipulative studies within an urban context have great potential. For instance, planting groupings of 
specific plants (e.g. currants) in clusters of yards over a period of years could allow a researcher to observe potential changes in species occurrences (e.g. rufous hummingbirds [Selasphorus rufus]). Despite these limitations, this study showed that Portland's landscape characteristics exert a strong influence on native bird assemblages.

\section{Community-based Science}

Overall, I garnered minimal interest from residents in my three study neighborhoods. Limited marketing resulted in the vast majority of people in the neighborhoods not knowing about the opportunity to participate with BirdCountPDX. In addition to marketing issues, barriers are known to exist which limiting individuals' availability to participate with projects like community-based science (e.g. money, time, access, background knowledge) (Hobbs \& White, 2012). BirdCountPDX asked a lot from participants, mainly it asked them to learn to identify birds on their own (if they were new to the hobby) and to commit at least a half hour a day once every other week, early on a weekday. These criteria immediately limited my pool of participants to those who had a background in birds and those who did not have existing obligations on occasional week day mornings, a time most people commute or work.

My participant pool reflected these limitations. Most participants had previous knowledge and experience birding, were currently students, or retired. Despite limited initial interest, I had good retention of participants. Of the 10 people who attended the training, 6 volunteers participated, collecting data at park stations or in their yards for a minimum of three times. 
As community-based science places emphasis on developing community, sense of place, and curriculum, BirdCountPDX was more of a community-based monitoring program than a place building community project. We attempted to monitor bird communities with the aid of community members, but curriculum was not developed and events were not organized to develop community or sense of place.

Organizations like the Audubon Society and The Cornell Lab of Ornithology have successful community-based science projects, drawing on the pool of interest that is already invested in them. They are able to utilize this social network to create robust opportunities for communities and science.

I recommend future community-based projects like mine to work alongside organization which have already developed community relationships. Science projects, working collaboratively with existing organizations would be a mutualistic relationship, where the science project could bring exciting new opportunities for engagement to the community and the project would benefit from increased visibility and participation.

\section{Recommendations for our Neighborhoods}

Creating healthier neighborhoods for both human and non-human residents is possible, not just at the municipal level or non-government organizational level, but even in our own yards. I recommend we focus more attention on softening the urban matrix, increasing connectivity between habitat patches, and expanding the "footprint" of our large urban green spaces. Further, I suggest we focus more of our resources towards creating large green spaces in our cities (> $10 \mathrm{ha}$ ). Though there are obvious 
monetary and space barriers, collaborative action between municipal agencies and nongovernmental organizations can help remove these barriers. Programs such as the Audubon Backyard Habitat Program give us a great example of how we can mobilize people to create change through our own backyards, change that has the potential to scale up and effect not just available bird habitat, but the choices we make concerning conservation. 


\section{Conclusion}

Portland, Oregon expects to see continued population growth and development over the following decades. Urbanization has been shown to push strong gradients of human population and development across cities. Anthropogenic disturbance on avifauna is widely studied and has been associated with decreases in species richness and diversity, filtering out less urban adapted foraging and breeding guilds. Large neighborhood green spaces have been shown to host large proportions of a region's native species richness, while the surrounding matrix is often viewed as a hostile "ocean" of urbanization. Recent literature has started to explore the conservation potential within collectives of yards, often located in suburban and exurban neighborhoods. The purpose of this thesis was to assess the landscape characteristics of three neighborhoods (Hillsdale, Lents, and Pearl) and their influence on native bird richness, abundance, and diversity. Understanding how the landscape we manage in our neighborhoods has the potential to better inform management decisions made by agencies and landowners.

Neighborhoods in this study had different landscape characteristics. Hillsdale was least subject to anthropogenic disturbance, had the most canopy cover (35\%). Lents varied substantially in levels of anthropogenic disturbance and was predominantly characterized by grass and herbaceous ground cover (31\%). The Pearl had the higher levels of anthropogenic disturbance and was $77 \%$ impervious surface.

Native bird community attributes (species richness, mean abundance, and diversity) differed statistically by neighborhood and by station type (recreational park, 
nature park, residential). Hillsdale had the greatest values for species richness, mean abundance, and species diversity, Lents was intermediate and Pearl had the lowest values. Within each neighborhood, recreational parks tended to have the lowest values of native avian community attributes. Similar values between residential sites and nature parks indicate that recreational parks reflect low quality bird habitat, whereas both nature parks and recreational areas provide more desirable habitat for more species. Though there were differences in community attributes, the species present within each neighborhood and park type tended to be very similar to each other, indicating that there is a relatively small species pool dominating Portland's suburban and urban avian communities.

Landscape characteristics were found to significantly predict native species richness, mean abundance, and diversity in multiple regression analysis across neighborhoods. The fact that regression models did not perform well within individual neighborhoods indicates that differences were due to neighborhood differences. Regional trends are still noteworthy, as increasing urbanization correlated with more even guild assemblages. As stations became more urban, insectivores and foliage gleaners dropped out of the community while omnivores, granivores, and ground foragers remained relatively unaffected. invasive species also tended to increase in abundance as urbanization increased 


\section{References}

Alberti, M., Marzluff, J. M., Shulenberger, E., Bradley, G., Ryan, C., \& Zumbrunnen, C. (2003). Integrating humans into ecology: opportunities and challenges for studying urban ecosystems. BioScience, 53(12), 1169-1179.

Alberti, M., \& Marzluff, J. M. (2004). Ecological resilience in urban ecosystems: Linking urban patterns to human and ecological functions. Urban Ecosystems, 7(3), 241-265.

Aronson, M. F. J., La Sorte, F. A., Nilon, C. H., Katti, M., Goddard, M. A., Lepczyk, C. A., ... Winter, M. (2014). A global analysis of the impacts of urbanization on bird and plant diversity reveals key anthropogenic drivers. Proceedings of the Royal Society B:

Biological Sciences, 281(1780).

Audubon Society of Portland (n.d.). Backyard Habitat Certification Program. https://backyardhabitats.org/certification-criteria/

Belaire, A., Whelan, C., \& Minor, E. (2014). Having our yards and sharing them too: the collective effects of yards on native bird species in an urban landscape. The Ecological Society of America, 24(8), 2132-2143.

Bonney, R., Cooper, C. B., Dickinson, J., Kelling, S., Phillips, T., Rosenberg, K. V, \& Shirk, J. (2009). Citizen Science : A Developing Tool for Expanding Science Knowledge and Scientific Literacy, 59(11), 977-984.

Chace, J. F., \& Walsh, J. J. (2006). Urban effects on native avifauna: A review. Landscape and Urban Planning, 74(1), 46-69.

Chamberlain, D. E., Cannon, A. R., \& Toms, M. P. (2004). Associations of Garden Birds with Gradients in Garden Habitat and Local Habitat. Nordic Society Oikos, 27(5), 589600.

Chamberlain, D. E., Gough, S., Vaughan, H., Vickery, J. A., \& Appleton, G. F. (2007). Determinants of bird species richness in public green spaces. Bird Study, 54(1), 87-97.

Clawges, R., Vierling, K., Vierling, L., \& Rowell, E. (2008). The use of airborne lidar to assess avian species diversity, density, and occurrence in a pine/aspen forest. Remote Sensing of Environment, 112(5), 2064-2073.

Conole, L. E., \& Kirkpatrick, J. B. (2011). Landscape and Urban Planning Functional and spatial differentiation of urban bird assemblages at the landscape scale. Landscape and Urban Planning, 100(1-2), 11-23. 
Conrad, C. C., \& Hilchey, K. G. (2011). A review of citizen science and community-based environmental monitoring : issues and opportunities, 273-291.

Crooks, K. R., Suarez, A. V, \& Bolger, D. T. (2004). Avian assemblages along a gradient of urbanization in a highly fragmented landscape, 115, 451-462.

Czech, B., Krausman, P. R., \& Devers, P. K. (2000). Economic Associations among Causes of Species Endangerment in the United States. BioScience, 50(7), 593.

Degraaf, R. M., Geis, A. D., \& Healy, P. A. (1991). Population and Habitat Surveys in Urban Areas. Landscape and Urhan Planning, 21, 181-188.

Donnelly, R., \& Marzluff, J. M. (2004). Impotrance of reserve size and landscape context to urban bird conservation. Conservation Biology, 18(3), 733-745.

Donnelly, R., \& Marzluff, J. M. (2006). Relative importance of habitat quantity, structure, and spatial pattern to birds in urbanizing environments. Urban Ecosystems, 9(2), 99117.

Environmental Systems Research Institute (ESRI). (2012). ArcGIS Release 10.5.1. Redlands, CA.

Evans, K. L., Newson, S. E., \& Gaston, K. J. (2009). Habitat influences on urban avian assemblages. Ibis, 151(1), 19-39.

Fernández-Juricic, E. (2000). Avifaunal Use of Wooded Streets in an Urban Landscape. Birds in Wooded Streets Fernández-Juricic Conservation Biology (Vol. 14).

Fernández-Juricic, E., \& Jokimäki, J. (2001). A habitat island approach to conserving birds in urban landscapes: Case studies from southern and northern Europe. Biodiversity and Conservation.

Gibbs, A. D. (2018). Understanding the Impacts of Urbanization on the Avian Community of Portland Oregon and Evaluation of the Portland Oregon Backyard Habitat Certification Program. Portland State University.

Goddard, M. A., Dougill, A. J., \& Benton, T. G. (2009). Scaling up from gardens: biodiversity conservation in urban environments. Trends in Ecology and Evolution, 25(2), 90-98.

Gotelli, Nicholas, J., \& Ellison, Aaron, M. (2013). A Primer of Ecological Statistics (Second). Sunderland, Massachusetts U.S.A.: Sinauer Associates, Inc. 
Gowaty, Patricia, A. (1984). House Sparrows Kill Eastern Bluebirds Author. Journal of Field Ornithology, 55(3), 378-380.

Hagerman, C. (2007). Shaping neighborhoods and nature : Urban political ecologies of urban waterfront transformations in Portland, Oregon, 24(4), 285-297.

Hedblom, M., Knez, I., \& Gunnarsson, B. (2017). Bird Diversity Improves the Well-Being of City Residents. In Enrique Murgui \& M. Hedblom (Eds.), Ecology and Conservation of Birds in Urban Environments (1st ed., pp. 287-305). Springer International Publishing.

Hennings, L. A., \& Edge, W. D. (2003). Riparian Bird Community Structure in Portland, Oregon: Habitat, Urbanization, and Spatial Scale Patterns. The Condor, 105(2), 288-302.

Hobbs, S. J., \& White, P. C. L. (2012). Motivations and barriers in relation to community participation in biodiversity recording. Journal for Nature Conservation, 20(6), 364-373.

Ingold, D. J. (1994). Influence of Nest-Site Competition between European Starlings and Woodpeckers. The Wilson Bulletin, 106(2), 227-241.

Ingold, D. J. (1996). Delayed Nesting Decreases Reproductive Success in Northern Flickers: Implications for Competition with European Starlings. Journal of Field Ornithology, 67(2), 321-326.

Jeschke, J. M., \& Strayer, D. L. (2005). Invasion success of vertebrates in Europe and North America. Proceedings of the National Academy of Sciences of the United States of America, 102(20), 7198-7202.

Jolliffe, I. T., \& Cadima, J. (2016). Principal component analysis : a review and recent developments Subject Areas. Phil.Trans.R.Soc.A, 374, 1-16.

Koenig, W. D. (2003). European Starlings and Their Effect on Native Cavity-Nesting Birds. Conservation Biology, 17(4), 1134-1140.

Lepczyk, C. A., La Sorte, F. A., Aronson, M. F. J., Goddard, M. A., Ian, M.-F., Nilton, C. H., \& Warren, P. S. (2017). Ecology and conservation of birds in urban environments. In $E$ Murgui \& M. Hedblom (Eds.), Ecology and Conservation of Birds in Urban Environments (pp. 1-525).

Linz, G. M., Homan, H. J., Gaulker, S. M., Penry, L. B., Bleier, W. J., Linz, G. M., Gaukler, S. M. (2007). European Starlings: a Review of an Invasive Species With Far-Reaching Impacts. In Managing Vertebrate Invasive Specise: Proceedings of an International Symposium. USDA/APHIS/WS, National Wildlife Research Center, Fort Collins, CO. 
Luck, M., \& Wu, J. (2002). A gradient analysis of urban landscape pattern: a case study from the Phoenix metropolitan region, Arizona, USA. Landscape Ecology, V17(4), 327339.

Wilson, E. O., \& MacArthur, R. H. (1967). The theory of island biogeography. Princeton, NJ.

Marzluff, J.M., \& Ewing, K. (2001). Restoration of Fragmented Landscapes for the Conservation of Birds : A General Framework and Specific Recommendations for Urbanizing Landscapes. Society for Ecological Restoration, 9(3), 280-292.

Marzluff, J. M. (2001). Worldwide urbanization and its effects on birds. Avian Ecology and Conservation in an Urbanizing World.

Marzluff, J. M. (2016). A decadal review of urban ornithology and a prospectus for the future. Ibis, 159(1), 1-13.

Marzluff, J. M., Bowman, R., \& Donnelly, R. (2001). A historical perspective on urban bird research: trends, terms, and approaches. Avian Ecology and Conservation in an Urbanizing World.

Mathieu, R., Freeman, C., \& Aryal, J. (2007). Mapping private gardens in urban areas using object-oriented techniques and very high-resolution satellite imagery. Landscape and Urban Planning, 81(3), 179-192.

McDonnell, M. J., \& Pickett, S. T. . (1990). Ecosystem Structure and Function along Urban-Rural Gradients: An Unexploited Opportunity for Ecology. Ecology, 71(4), 12321237.

McKinney, M. (2002). Urbanization, Biodiversity, and Conservation. BioScience, 52(10).

Miller, J. R. (2005). Biodiversity conservation and the extinction of experience. Trends in Ecology and Evolution, 20(8), 430-434.

Munyenyembe, F., Harris, J., \& Hone, J. (1989). Determinants of bird populations in an urban area. Australian Journal of Ecology, 14, 549-557.

Narango, D. L., Tallamy, D. W., \& Marra, P. P. (2017). Native plants improve breeding and foraging habitat for an insectivorous bird. Biological Conservation, 213(March), 4250 .

Newton, I. (1994). The role of nest sites in limiting the numbers of hole-nesting birds: a review. Biological Conservation, 70(3), 265-276. 
Nielsen, A. B., van den Bosch, M., Maruthaveeran, S., \& van den Bosch, C. K. (2014). Species richness in urban parks and its drivers: A review of empirical evidence. Urban Ecosystems, 17(1), 305-327.

NRCS. (n.d.). Backyard Conservation: bringing conservation frrom the countryside to the backyard.

Pennington, D. N., \& Blair, R. B. (2012). Using Gradient Analysis to Uncover Pattern and Process in Urban Bird Communities. (C. A. Lepczyk \& P. S. Warren, Eds.), Urban Bird Ecology and Conservation (1st ed.). University of California Press.

Pickard, B. R., Daniel, J., Mehaffey, M., Jackson, L. E., \& Neale, A. 2015. EnviroAtlas: A new geospatial tool to foster ecosystem services science and resource management. Ecosystem Services, 14, 45-55.

R Core Team (2018). R: A language and environment for statistical computing. $R$ Foundation for Statistical Computing, Vienna, Austria. URL https://www.R-project.org/.

Rodewald, A. D. (2012). Evaluating Factors that Influence Avian Community Response to Urbanization. In C. A. Lepczyk \& P. S. Warren (Eds.), Urban Bird Ecology and Conservation. Studies in Avian Biology (45th ed., pp. 71-92). Berkeley, CA: University of California Press.

Rodewald, P. (Editor). 2015. The Birds of North America: https://birdsna.org. Cornell Laboratory of Ornithology, Ithaca, NY.

Sedgwich, J. A., \& Knopf, Fritz, L. (1990). Habitat Relationships and Nest Site Characteristics of Cavity-Nesting Birds in Cottonwood Floodplains. The Journal of Wildlife Management, 54(1), 112-124.

Shannon, C. E., \& Weaver, W. (1948). The Mathematical Theory of Communication. Bell System Technical Journal, 27(3), 379-423.

Smith, R. M., Gaston, K. J., Warren, P. H., \& Thompson, K. (2006). Urban domestic gardens (VIII): Environmental correlates of invertebrate abundance. Biodiversity and Conservation, 15(8), 2515-2545.

Smith, R. M., Warren, P. H., Thompson, K., \& Gaston, K. J. (2006). Urban domestic gardens (VI): Environmental correlates of invertebrate species richness. Biodiversity and Conservation, 15(8), 2415-2438. 
Soga, M., Yamaura, Y., Koike, S., \& Gaston, K. J. (2014). Land sharing vs. land sparing: Does the compact city reconcile urban development and biodiversity conservation? Journal of Applied Ecology, 51(5), 1378-1386.

Sparks, T. H., Huber, K., \& Tryjanowski, P. (2008). Something for the weekend? Examining the bias in avian phenological recording. International Journal of Biometeorology, 52(6), 505-510.

Sullivan, B. L., Wood, C. L., Iliff, M. J., Bonney, R. E., Fink, D., \& Kelling, S. (2009). eBird : A citizen-based bird observation network in the biological sciences. Biological Conservation, 142(10), 2282-2292.

Tremblay, M. A., \& St. Clair, C. C. (2011). Permeability of a heterogeneous urban landscape to the movements of forest songbirds. Journal of Applied Ecology, 48(3), 679688.

Verner, J., \& Ritter, L. V. (1986). Hourly Variation in Morning Point Counts of Birds. The Auk, 103(1), 117-124.

Vignoli, L., Scirè, S., \& Bologna, M. A. (2013). Rural-urban gradient and land use in a millenary metropolis: How urbanization affects avian functional groups and the role of old villas in bird assemblage patterning. Web Ecology, 13, 49-67.

Whelan, C. J., Wenny, D. G., \& Marquis, R. J. (2008). Ecosystem Services Provided by Birds. Annals of the New York Academy of Sciences, 1134(1), 25-60.

Wiens, J. A. (1995). Habitat fragmentation: island v landscape perspectives on bird conservation. Ibis, 137, 97-104.

Zhang, X. Q. (2016). The trends, promises and challenges of urbanisation in the world. Habitat International, 54(13), 241-252. 


\section{Appendix A. Species Observed}

Table 3. All species observed during this study. Foraging guild, diet, nesting guild, and winter status (resident or migratory) determined from species accounts on the online Birds of North America database (Rodewald, 2015).

\begin{tabular}{|c|c|c|c|c|c|c|}
\hline Common Name & $\begin{array}{l}\text { Scientific } \\
\text { Name }\end{array}$ & Code & $\begin{array}{l}\text { Foraging } \\
\text { Guild }\end{array}$ & Diet & $\begin{array}{l}\text { Nesting } \\
\text { Guild }\end{array}$ & Winter \\
\hline American Crow & $\begin{array}{l}\text { Corvus } \\
\text { brachyrhynchos }\end{array}$ & AMCR & ground & omnivore & tree & res \\
\hline $\begin{array}{l}\text { American } \\
\text { Goldfinch }\end{array}$ & Spinus tristis & AMGO & foliage & seeds & shrub & res \\
\hline American Robin & $\begin{array}{l}\text { Turdus } \\
\text { migratorius }\end{array}$ & AMRO & ground & insects & tree & res \\
\hline $\begin{array}{l}\text { Anna's } \\
\text { Hummingbird }\end{array}$ & Calypte anna & ANHU & nectar & nectar & tree & res \\
\hline $\begin{array}{l}\text { Black-capped } \\
\text { Chickadee }\end{array}$ & $\begin{array}{l}\text { Poecile } \\
\text { atricapillus }\end{array}$ & $\mathrm{BCCH}$ & foliage & insects & cavity & res \\
\hline Bewick's Wren & $\begin{array}{l}\text { Thryomanes } \\
\text { bewickii }\end{array}$ & BEWR & foliage & insects & cavity & res \\
\hline $\begin{array}{l}\text { Brown-headed } \\
\text { Cowbird }\end{array}$ & Molothrus ater & $\mathrm{BHCO}$ & ground & seeds & parasitic & res \\
\hline $\begin{array}{l}\text { Brewer's } \\
\text { Blackbird }\end{array}$ & $\begin{array}{l}\text { Euphagus } \\
\text { cyanocephalus }\end{array}$ & BRBL & ground & insects & shrub & res \\
\hline Brown Creeper & $\begin{array}{l}\text { Certhia } \\
\text { americana }\end{array}$ & $\mathrm{BRCR}$ & bark & insects & tree & res \\
\hline Bushtit & $\begin{array}{l}\text { Psaltriparus } \\
\text { minimus }\end{array}$ & BUSH & foliage & insects & tree & res \\
\hline $\begin{array}{l}\text { California Scrub- } \\
\text { Jay }\end{array}$ & $\begin{array}{l}\text { Aphelocoma } \\
\text { californica }\end{array}$ & CASJ & ground & omnivore & tree & res \\
\hline $\begin{array}{l}\text { Chestnut-backed } \\
\text { Chickadee }\end{array}$ & $\begin{array}{l}\text { Poecile } \\
\text { rufescens }\end{array}$ & $\mathrm{CBCH}$ & foliage & insects & cavity & res \\
\hline Cedar Waxwing & $\begin{array}{l}\text { Bombycilla } \\
\text { cedrorum }\end{array}$ & CEDW & foliage & fruit & tree & res \\
\hline $\begin{array}{l}\text { Downy } \\
\text { Woodpecker }\end{array}$ & $\begin{array}{l}\text { Dryobates } \\
\text { pubescens }\end{array}$ & DOWO & bark & insects & cavity & res \\
\hline Fox Sparrow & $\begin{array}{l}\text { Passerella } \\
\text { iliaca }\end{array}$ & FOSP & ground & insects & ground & mig \\
\hline $\begin{array}{l}\text { Golden Crowned } \\
\text { Kinglet }\end{array}$ & $\begin{array}{l}\text { Regulus } \\
\text { satrapa }\end{array}$ & GCKI & foliage & insects & tree & res \\
\hline House Finch & $\begin{array}{l}\text { Haemorhous } \\
\text { mexicanus }\end{array}$ & HOFI & ground & seeds & tree & res \\
\hline Killdeer & $\begin{array}{l}\text { Charadrius } \\
\text { vociferus }\end{array}$ & KILL & ground & insects & ground & res \\
\hline
\end{tabular}




\begin{tabular}{|c|c|c|c|c|c|c|}
\hline Lesser Goldfinch & Spinus psaltria & LEGO & foliage & seeds & tree & res \\
\hline Mourning dove & $\begin{array}{l}\text { Zenaida } \\
\text { macroura }\end{array}$ & MODO & ground & seeds & tree & res \\
\hline Northern Flicker & $\begin{array}{l}\text { Colaptes } \\
\text { auratus }\end{array}$ & NOFL & ground & insects & cavity & res \\
\hline $\begin{array}{l}\text { Orange-crowned } \\
\text { Warbler }\end{array}$ & $\begin{array}{l}\text { Oreothlypis } \\
\text { celata }\end{array}$ & OCWA & foliage & insects & ground & mig \\
\hline Dark-eyed Junco & Junco hyemalis & DEJU & ground & seeds & tree & res \\
\hline Pine Siskin & Spinus pinus & PISI & foliage & seeds & tree & res \\
\hline $\begin{array}{l}\text { Red-breasted } \\
\text { Nuthatch }\end{array}$ & $\begin{array}{l}\text { Sitta } \\
\text { canadensis }\end{array}$ & RBNU & bark & insects & cavity & res \\
\hline $\begin{array}{l}\text { Red-breasted } \\
\text { Sapsucker }\end{array}$ & $\begin{array}{l}\text { Sphyrapicus } \\
\text { ruber }\end{array}$ & RBSA & bark & insects & cavity & res \\
\hline Red-tailed Hawk & $\begin{array}{l}\text { Buteo } \\
\text { jamaicensis }\end{array}$ & RTHA & raptor & carnivore & tree & res \\
\hline Song Sparrow & $\begin{array}{l}\text { Melospiza } \\
\text { melodia }\end{array}$ & SOSP & ground & insects & shrub & res \\
\hline Spotted Towhee & $\begin{array}{l}\text { Pipilo } \\
\text { maculatus }\end{array}$ & SPTO & ground & omnivore & ground & res \\
\hline $\begin{array}{l}\text { Sharp-shinned } \\
\text { Hawk }\end{array}$ & $\begin{array}{l}\text { Accipiter } \\
\text { striatus }\end{array}$ & SSHA & raptor & carnivore & tree & res \\
\hline Steller's Jay & $\begin{array}{l}\text { Cyanocitta } \\
\text { stelleri }\end{array}$ & STJA & ground & omnivore & tree & res \\
\hline $\begin{array}{l}\text { White-crowned } \\
\text { Sparrow }\end{array}$ & $\begin{array}{l}\text { Zonotrichia } \\
\text { leucophrys }\end{array}$ & WCSP & ground & insects & ground & mig \\
\hline Western Tanager & $\begin{array}{l}\text { Piranga } \\
\text { ludoviciana }\end{array}$ & WETA & foliage & insects & tree & mig \\
\hline $\begin{array}{l}\text { Western Wood- } \\
\text { Pewee }\end{array}$ & $\begin{array}{l}\text { Contopus } \\
\text { sordidulus }\end{array}$ & WEWP & foliage & insects & tree & mig \\
\hline $\begin{array}{l}\text { Willow } \\
\text { Flycatcher }\end{array}$ & $\begin{array}{l}\text { Empidonax } \\
\text { traillii }\end{array}$ & WIFL & foliage & insects & shrub & mig \\
\hline Wilson's Warbler & $\begin{array}{l}\text { Cardellina } \\
\text { pusilla }\end{array}$ & WIWA & foliage & insects & ground & mig \\
\hline $\begin{array}{l}\text { Eurasian } \\
\text { Collared-Dove }\end{array}$ & $\begin{array}{l}\text { Streptopelia } \\
\text { decaocto }\end{array}$ & EUCD & ground & seeds & tree & inv \\
\hline $\begin{array}{l}\text { European } \\
\text { Starling }\end{array}$ & $\begin{array}{l}\text { Sturnus } \\
\text { vulgaris }\end{array}$ & EUST & ground & insects & cavity & inv \\
\hline House Sparrow & $\begin{array}{l}\text { Passer } \\
\text { domesticus }\end{array}$ & HOSP & ground & seeds & cavity & inv \\
\hline Rock Pigeon & Columba livia & ROPI & ground & seeds & building & inv \\
\hline
\end{tabular}




\section{Appendix B. Regression Results}

Table 4. Model outputs for multiple regressions of landcover at three scales: landscape (referred to as regional in figure), local, and immediate (referred to as station in figure). Independent variables are UI, percent impervious cover, percent herbaceous or grass cover, number of buildings within the buffer, number of point count station visits, percent canopy cover, and total population within the buffer. Estimated regression coefficients for landscape variables and model $R^{2}$ values for best multiple regression models selected using AICc (delta AIC less than or equal to 2). Multiple regressions report adjusted R2. Each cell reports the coefficient first with significance level as asterisks, second is the $p$-value and standard error on the bottom. Table on following page 


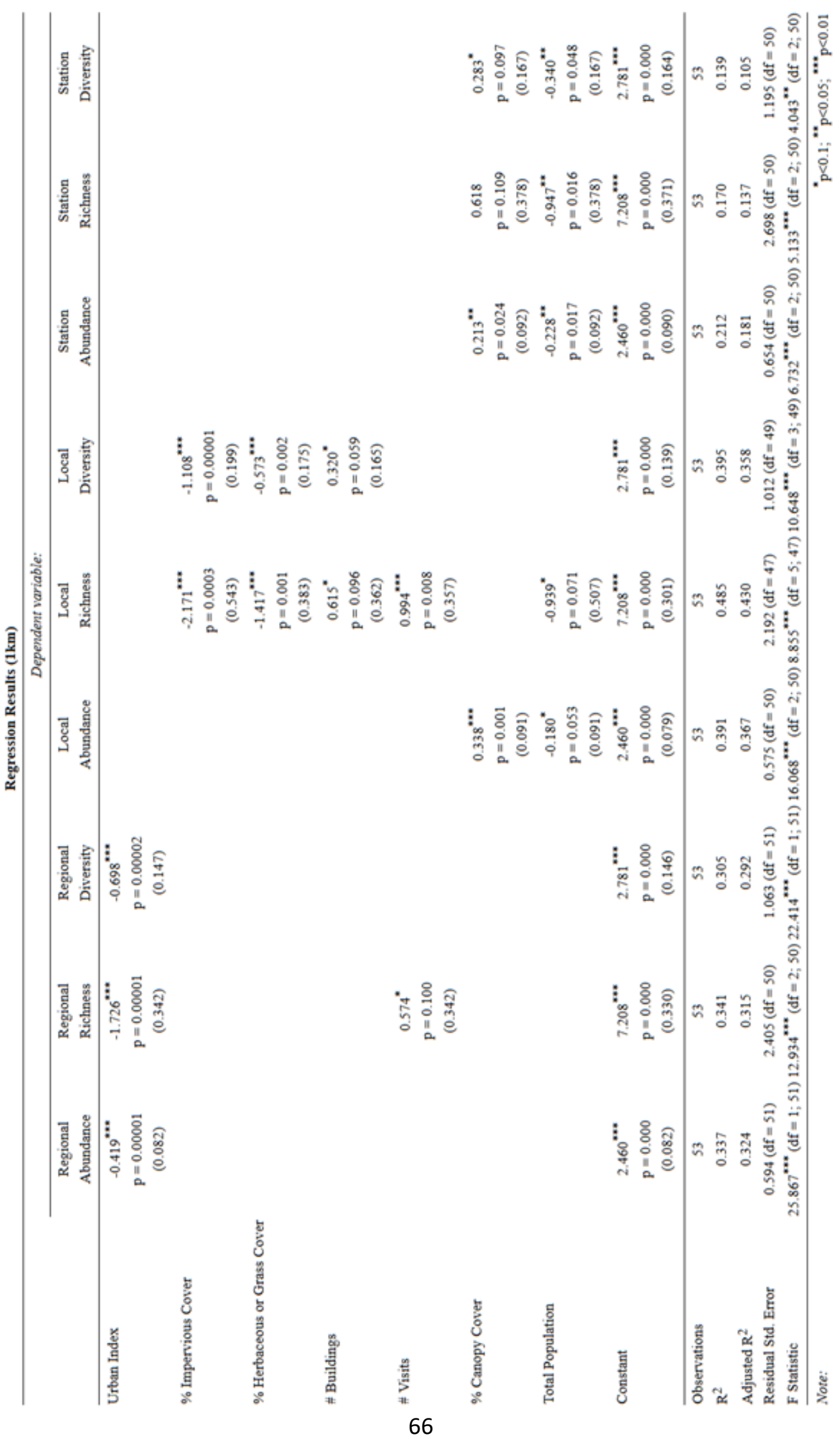


Table 5. Full model of local-landscape variables (10ha area centered on each station). Dependent variables are native species abundance ${ }^{1 / 2}$, native species diversity ${ }^{2}$, and native species richness. Independent variables were the same as the partial landscape model, with average abundance of invasive birds per station, distance to parks (small, medium, large), and UI were included. Estimated regression coefficients shown for landscape variables along with model $R^{2}$ values for best multiple regression models selected using AICc (delta AIC less than or equal to 2). Multiple regressions report adjusted R2. Each cell reports the coefficient first with significance level as asterisks, second is the pvalue and standard error on the bottom. Independent variables are standardized ( $\mathrm{z}$ score) allowing for coefficient comparison.

Local Landcover Full Model (10ha)

\begin{tabular}{|c|c|c|c|}
\hline & \multicolumn{3}{|c|}{ Dependent variable: } \\
\hline & Abundance & Richness & Diversity \\
\hline Distance to Large Park & $\begin{array}{c}-0.228^{* * *} \\
\mathrm{p}=0.004 \\
(0.075)\end{array}$ & $\begin{array}{c}-1.273^{* * *} \\
\mathrm{p}=0.0002 \\
(0.313)\end{array}$ & \\
\hline$\%$ Impervious & $\begin{array}{c}-0.295^{* * *} \\
p=0.005 \\
(0.098)\end{array}$ & $\begin{array}{c}-1.280^{* *} \\
p=0.013 \\
(0.494)\end{array}$ & $\begin{array}{c}-0.742^{* * *} \\
p=0.006 \\
(0.257)\end{array}$ \\
\hline Invasive Abundance & $\begin{array}{c}-0.185^{*} \\
\mathrm{p}=0.066 \\
(0.098)\end{array}$ & & \\
\hline$\%$ Herbaceous or Grass Cover & & & $\begin{array}{c}-0.485^{* * *} \\
p=0.008 \\
(0.173)\end{array}$ \\
\hline Buildings & & $\begin{array}{c}0.687^{*} \\
p=0.060 \\
(0.356)\end{array}$ & $\begin{array}{c}0.346^{* *} \\
p=0.036 \\
(0.160)\end{array}$ \\
\hline Population & & $\begin{array}{c}-1.083^{* *} \\
p=0.036 \\
(0.501)\end{array}$ & \\
\hline Visits & & $\begin{array}{c}1.190^{* * *} \\
p=0.002 \\
(0.357)\end{array}$ & \\
\hline Urban Index & & & $\begin{array}{c}-0.445^{* *} \\
\mathrm{p}=0.038 \\
(0.208)\end{array}$ \\
\hline Constant & $\begin{array}{c}2.460^{* * *} \\
\mathrm{p}=0.000 \\
(0.074)\end{array}$ & $\begin{array}{c}7.208^{* * *} \\
p=0.000 \\
(0.294)\end{array}$ & $\begin{array}{c}2.781^{* * *} \\
p=0.000 \\
(0.134)\end{array}$ \\
\hline Observations & 53 & 53 & 53 \\
\hline $\mathrm{R}^{2}$ & 0.471 & 0.508 & 0.448 \\
\hline Adjusted $\mathrm{R}^{2}$ & 0.438 & 0.456 & 0.402 \\
\hline Residual Std. Error & $0.542(\mathrm{df}=49)$ & $2.142(\mathrm{df}=47)$ & $0.977(\mathrm{df}=48)$ \\
\hline F Statistic & $14.532^{* * *}(\mathrm{df}=3 ;$ & $720^{* * *}(\mathrm{df}=5 ; 4$ & $721^{* * *}(\mathrm{df}=4 ; 48)$ \\
\hline
\end{tabular}




\begin{tabular}{|c|c|c|c|c|}
\hline \multicolumn{4}{|c|}{ Yard Vegetative Structure Model } & \multirow{6}{*}{$\begin{array}{l}\text { Table } 6 \text {. Models predicting avian community } \\
\text { traits in residential areas with yards. Two } \\
\text { models were created to compare the influence } \\
\text { of vegetative structure with landscape } \\
\text { characteristics at the local scale. Estimated } \\
\text { regression coefficients shown for landscape } \\
\text { variables along with model } \mathrm{R}^{2} \text { values for best } \\
\text { multiple regression models selected using AICc } \\
\text { (delta AIC less than or equal to } 2 \text { ). Multiple } \\
\text { regressions report adjusted } \mathrm{R} 2 \text {. Asterisks } \\
\text { indicate significance level: } * p<0.1, * * p<0.05 \text {, }\end{array}$} \\
\hline & \multicolumn{3}{|c|}{ Dependent variable: } & \\
\hline & Abundance & Richness & Diversity & \\
\hline \multirow[t]{2}{*}{$\%$ Herbaceous } & $1.540^{* * *}$ & $1.816^{* * *}$ & $0.199^{* * *}$ & \\
\hline & $\begin{array}{c}p=0.007 \\
(0.520)\end{array}$ & $\begin{array}{c}\mathrm{p}=0.00004 \\
(0.357)\end{array}$ & $\begin{array}{c}p=0.0002 \\
(0.043)\end{array}$ & \\
\hline Constant & $\begin{array}{c}7.435^{* * *} \\
p=0.000 \\
(0.510)\end{array}$ & $\begin{array}{c}8.222^{* * *} \\
\mathrm{p}=0.000 \\
(0.351)\end{array}$ & $\begin{array}{c}1.807^{* * *} \\
\mathrm{p}=0.000 \\
(0.043)\end{array}$ & \\
\hline Observations & 27 & 27 & 27 & \multirow{9}{*}{$\begin{array}{l}* * * p<0.01 \text { Yard vegetative model included six } \\
\text { independent variables: overstory and } \\
\text { understory canopy, large and small shrub } \\
\text { layers, herbaceous ground cover, and number } \\
\text { of station visits. Yard landscape model included } \\
\text { six independent variables: nearest large park, } \\
\text { percent herbaceous and or grass cover, total } \\
\text { human population, UI, average number of } \\
\text { invasive birds observed, and number of station } \\
\text { visits. }\end{array}$} \\
\hline $\mathrm{R}^{2}$ & 0.260 & 0.508 & 0.458 & \\
\hline Adjusted $\mathrm{R}^{2}$ & 0.230 & 0.489 & 0.436 & \\
\hline Residual Std. Error $(\mathrm{df}=25)$ & 2.649 & 1.821 & 0.221 & \\
\hline F Statistic $(\mathrm{df}=1 ; 25)$ & $8.784^{* * *}$ & $25.843^{* * *}$ & $21.087^{* * *}$ & \\
\hline Note: & ${ }^{*} \mathrm{p}<0$ & $.1 ;^{* *} \mathrm{p}<0.05$ & ${ }^{* * *} \mathrm{p}<0.01$ & \\
\hline \multicolumn{4}{|c|}{ Yard - Landscape Characteristic Model } & \\
\hline & \multicolumn{3}{|c|}{ Dependent variable: } & \\
\hline & Abundance & Richness & Diversity & \\
\hline \multirow[t]{2}{*}{ Distance to Large Park } & $-2.040^{* * *}$ & $-1.866^{* * *}$ & $-0.186^{* * *}$ & \\
\hline & $\begin{array}{c}\mathrm{p}=0.0002 \\
(0.445)\end{array}$ & $\begin{array}{c}\mathrm{p}=0.00002 \\
(0.347)\end{array}$ & $\begin{array}{c}p=0.0005 \\
(0.046)\end{array}$ & \\
\hline Constant & $\begin{array}{c}7.435^{* * *} \\
p=0.000 \\
(0.437)\end{array}$ & $\begin{array}{c}8.222^{* * *} \\
p=0.000 \\
(0.340)\end{array}$ & $\begin{array}{c}1.807^{* * *} \\
\mathrm{p}=0.000 \\
(0.045)\end{array}$ & \\
\hline Observations & 27 & 27 & 27 & \\
\hline $\mathrm{R}^{2}$ & 0.456 & 0.537 & 0.399 & \\
\hline Adjusted $\mathrm{R}^{2}$ & 0.434 & 0.518 & 0.375 & \\
\hline Residual Std. Error $(\mathrm{df}=25)$ & 2.271 & 1.768 & 0.232 & \\
\hline F Statistic $(\mathrm{df}=1 ; 25)$ & $20.976^{* * *}$ & $28.967^{* * *}$ & $16.624^{* * *}$ & \\
\hline Note: & \multicolumn{3}{|c|}{${ }^{*} \mathrm{p}<0.1 ;{ }^{* *} \mathrm{p}<0.05 ;{ }^{* * *} \mathrm{p}<0.01$} & \\
\hline
\end{tabular}

